\title{
Role of NADPH Oxidase in Formation and Function of Multinucleated Giant Cells
}

\author{
Mark T. Quinn Igor A. Schepetkin \\ Department of Veterinary Molecular Biology, Montana State University, Bozeman, Mont., USA
}

\author{
Key Words \\ Macrophage fusion - Reactive oxygen species $\cdot \mathrm{NADPH}$ \\ oxidase - Superoxide anion - Osteoclast · Giant cell · \\ Granuloma $\cdot$ Inflammation $\cdot$ Innate immunity
}

\begin{abstract}
Macrophages play essential roles in a wide variety of physiological and pathological processes. One of the unique features of these phagocytic leukocytes is their ability to fuse, forming multinucleated giant cells. Multinucleated giant cells are important mediators of tissue remodeling and repair and are also responsible for removal or sequestration of foreign material, intracellular bacteria and non-phagocytosable pathogens, such as parasites and fungi. Depending on the tissue where fusion occurs and the inflammatory insult, multinucleated giant cells assume distinctly different phenotypes. Nevertheless, the ultimate outcome is the formation of large cells that can resorb bone tissue (osteoclasts) or foreign material and pathogens (giant cells) extracellularly. While progress has been made in recent years, the mechanisms and factors involved in macrophage fusion are still not fully understood. In addition to cytokines and a number of adhesion proteins and receptors, it is becoming increasingly clear that NADPH oxidase-generated reactive oxygen species (ROS) also play an important role in macrophage fusion. In this review, we provide an overview of macrophage multinucleation, with a specific focus on the role of NADPH oxidases and ROS in macrophage fusion and in the function of
\end{abstract}

multinucleated giant cells. In addition, we provide an updated overview of the role of these cells in inflammation and various autoimmune diseases.

Copyright $\odot 2009$ S. Karger AG, Basel

\section{Introduction}

Multinucleated giant cells are formed by the fusion of macrophages and play important roles in a number of physiological and pathological processes [reviewed in 1, 2]. These cells were first described by Langhans [3], who reported the presence of polynuclear cells in tuberculoid granulomas. Subsequent work to these pioneering observations has shown that multinucleated giant cells are formed as a result of fusion of cells belonging to the monocyte/macrophage lineage and represent one pathway for terminal differentiation of macrophages $[1,2]$. Thus, the formation of giant cells represents a process of natural homotypical hybridization of cells, leading to the modulation of synthetic and secretory functions of macrophages. In healthy individuals, multinucleated giant cells are found in bone, where they are known as osteoclasts [4]. However, the formation of giant cells in nonskeletal tissues can arise as a result of chronic inflammation due to the presence of foreign material that is indigestible/poorly digestible or persistent pathogens that are not killed for various reasons. The physiological role of multinucleated giant cells in innate immunity includes

Dr. Mark T. Quinn

Department of Veterinary Molecular Biology

Montana State University

Bozeman, MT 59717 (USA)

Tel. +1 406994 4707, Fax +1 406994 4303,E-Mail mquinn@montana.edu 
remodeling of granuloma-associated extracellular matrix and clearance of foreign particles from tissues. Furthermore, they can participate in clearance of apoptotic debris during some infections [5]. While mononucleated macrophages degrade internalized targets in phagolysosomes, the overall role of multinucleated macrophages is to resorb large areas of bone tissue (osteoclasts) or foreign material and pathogens (giant cells) extracellularly.

The mechanisms involved in the formation of multinucleated giant cells are not well understood and are only recently being defined. However, it is clear that a number of soluble factors (such as cytokines and growth factors) and cellular fusion machinery (such as receptors and ligands) are involved [reviewed in 1, 2, 6]. This review focuses on recent efforts to develop a better understanding of the role of NADPH oxidases and reactive oxygen species (ROS) in macrophage fusion and in the function of multinucleated giant cells.

\section{Types of Multinucleated Giant Cells}

Multinucleated giant cells can be classified into several morphological variants depending on the arrangement and composition of their organelles, as well as their functional characteristics (fig. 1). These variants include foreign-body giant cells, Langhans giant cells, Touton giant cells, osteoclast-like cells and osteoclasts. Since all giant cell variants are derived from monocyte/macrophage precursors, their morphological and functional heterogeneity seems to be determined by the specific tissue location and local factors present in the milieu where cell fusion occurs.

Foreign-body giant cells contain many nuclei (up to 100-200) that are arranged in a diffuse manner throughout the cytoplasm (fig. $2 a$ and b). In comparison, the nuclei of Langhans giant cells are located on the periphery surrounding the Golgi complex and other organelles (fig. 2a). Touton giant cells are characterized by multiple nuclei that cluster together in the cell and are surrounded by a foamy cytoplasm (fig. 2c). These cells were originally known as xanthelasmatic giant cells and are formed by fusion of macrophage-derived foam cells $[7,8]$. Touton giant cells are most frequently found in lesions containing cholesterol and lipid deposits, and are associated with various pathologic processes, such as xanthomas and xanthogranulomas $[9,10]$.

Morphologically, osteoclasts are closer to foreignbody giant cells, although they have considerably fewer nuclei (fig. 1). Both originate from fusion of mononuclear phagocytes, and many functional markers are common to osteoclasts and giant cells $[11,12]$. The basic physiological role of the osteoclasts is extracellular resorption of mineral and organic bone matrix components. In descriptions of the histological structure of giant cell tumors and several pathological lesions, the term osteoclast-like cell is often used. This term is applied on the basis of morphological similarities of these multinucleated cells to osteoclasts; however, osteoclast-like cells usually have a higher number of nuclei than osteoclasts [13].

\section{Formation of Multinucleated Giant Cells: Role of Cytokines, Membrane Receptors and Adhesion Proteins}

As indicated above, multinucleated giant cells are formed through fusion of monocyte/macrophages that are recruited to bone (osteoclasts), persistent microbial infections (Langhans cells, immune giant cells) or nonphagocytosable foreign material (foreign-body giant cells). While these various types of giant cells are characterized by distinct morphological and functional features, their formation involves both common and variant-specific fusion mechanisms $[1,2,6]$. On the whole, macrophage fusion has been shown to involve a number of soluble or membrane-bond protein factors that promote hydrophobic contacts between cells and mediate subsequent membrane reorganization and cell fusion, and these factors are briefly summarized below and illustrated in figure 3. Additionally, several recent reviews are available for further details on factors involved in macrophage fusion $[1,2,6]$. Note that the experimental conditions used to define these factors range from in vitro to in vivo and involve primary cells as well as various monocyte/macrophage cell lines from both human and other mammalian sources. Thus, consideration of these factors is required when making conclusions regarding their physiological roles in macrophage fusion in the host. For example, in vitro systems clearly cannot replicate the milieu and cellular environment experienced by multinucleated giant cell precursor systems in vivo, and it is evident that a complex interplay of soluble factors and substrates is involved in this process. Nevertheless, it is helpful to consider the major factors reported to be involved in macrophage fusion, regardless of the experimental systems, in order to develop a better understanding of this process and to consider points of intersection or interplay between these factors and the downstream signals induced. 

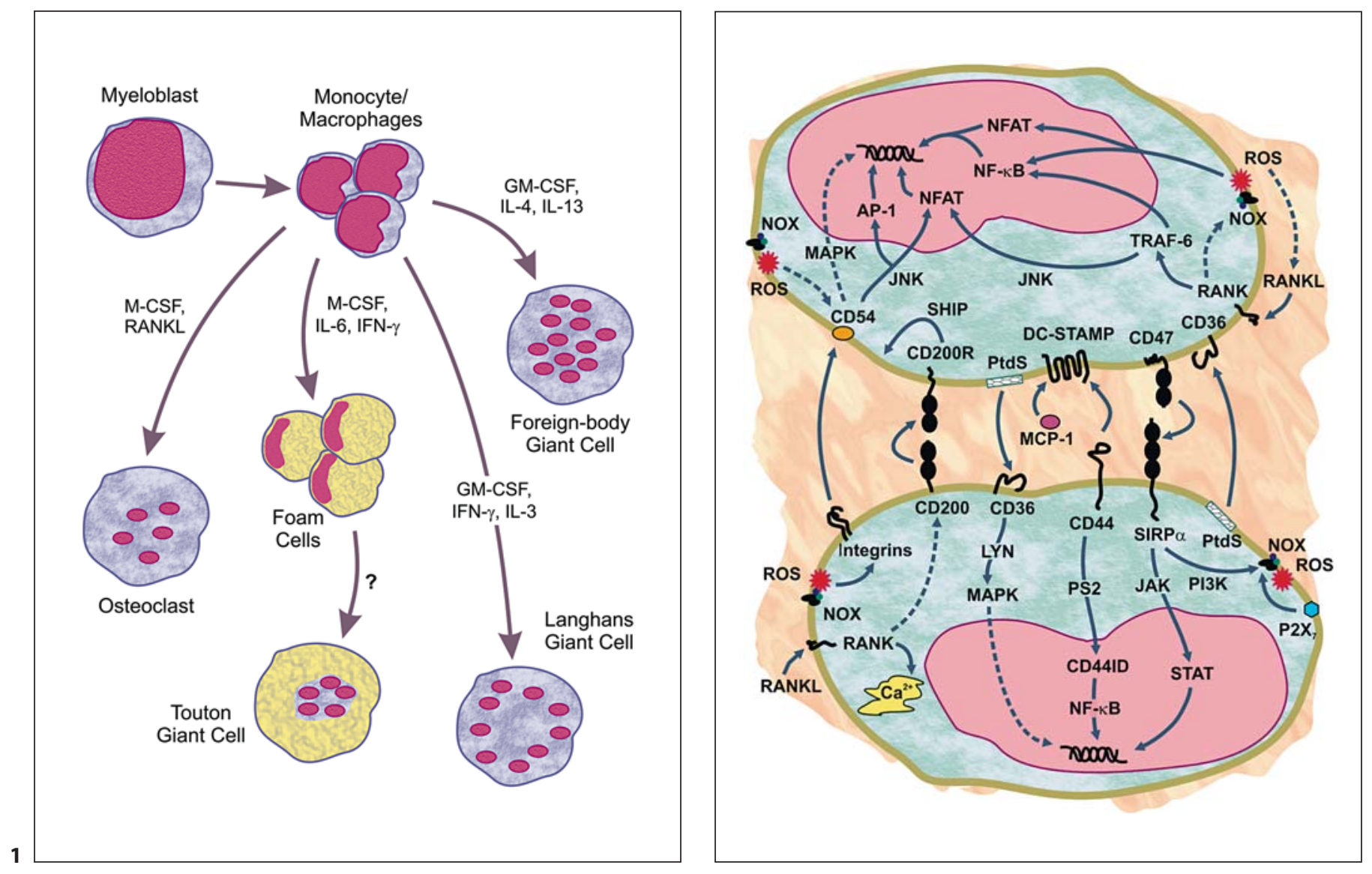

3

Fig. 1. Types of multinucleated giant cells derived from monocyte/macrophage precursors. Pathways leading to formation of the primary types of munlinucleated macrophages are shown. Major cytokines known to be involved in the differentiation/fusion of monocyte/macrophage precursors are indicated. Proposed pathways that are not well defined are indicated by dashed lines. $\mathrm{M}-\mathrm{CSF}=$ Macrophage colony-stimulating factor; GM-CSF = granulocyte-macrophage colony-stimulating factor; RANKL = receptor activator for nuclear factor- $\kappa \mathrm{B}$ ligand; IL-3 = interleukin 3; IL-4 = interleukin 4; IL-6 = interleukin 6; IL-13 = interleukin 13 ; IFN- $\gamma=$ interferon- $\gamma$. See text for further details.

Fig. 2. Histological images of multinucleated giant cells. a Langhans giant cells and one foreign-body giant cell (arrow) in a granuloma composed entirely of multinucleated giant cells. b Foreignbody giant cell. c Touton giant cell from a cutaneous juvenile xanthogranuloma. Images provided courtesy of Yale Rosen.

(For legend of figure 3 see next page.) 


\section{Cytokines}

Cytokines play a key role in macrophage fusion; however, exposure of cells to different cytokine combinations induces distinct types of multinucleated giant cells (fig. 1; table 1). For example, osteoclasts arise from treatment of bone marrow-derived macrophages with macrophage colony-stimulating factor (M-CSF) and receptor activator for nuclear factor (NF)-кB (RANK) ligand (RANKL) [14]. In contrast, stimulation of macrophages with interleukin (IL)-4 [15] or IL-13 [16], or a combination of IL-4 and granulocyte-macrophage colony-stimulating factor (GM-CSF) [17], leads to formation of foreign-body giant cells. On the other hand, the formation of Langhans giant cells requires interferon (IFN)- $\gamma$ and IL-3 [18], and the formation of foam cells is promoted by M-CSF, IL- 6 and IFN- $\gamma[19,20]$. Based on the role of these cytokines in the formation of other multinucleated macrophages, it is plausible that they are involved in Touton giant cell formation; however, the role of these cytokines in foam cell fusion has not been described.

RANKL induces $\mathrm{Ca}^{2+}$ oscillations, activation of c-Jun $\mathrm{N}$-terminal kinase (JNK) and activation of NF- $\mathrm{KB}$ and nuclear factor of activated T cells (NFAT) [21, 22] (fig. 3). Furthermore, $\mu$-calpain, a $\mathrm{Ca}^{2+}$-dependent protease, is has been reported to participate in the regulation of RANKL-mediated macrophage multinucleation via NF- $\kappa \mathrm{B}$ [23]. While mice lacking RANKL or RANK cannot form osteoclasts [reviewed in 24], RANKL-independent systems for activation of macrophage multinucleation have also been reported. For example, various combinations of TNF- $\alpha$, lipopolysaccharide (LPS) and peptidoglycan have been reported to promote macrophage fusion and osteoclast formation [25]. Note, however, that it is possible that thesemediators may serve to mimicRANKLinduced signaling via their ability to activate JNK and NF-кB.

Based on the types of cytokines and environmental factors encountered, monocyte/macrophages have been shown to assume polarized functional characteristics and are broadly classified into 2 groups: M1 and M2 macrophages [reviewed in 26,27]. This classification parallels the Th1/Th2 nomenclature, whereby M1 macrophages are defined as classically activated cells that are stimulated by inflammatory cytokines, such as IFN- $\gamma$ alone or in combination with microbial products (for example, LPS) or other cytokines (for example, TNF- $\alpha$, GM-CSF and IL-6) and have a pro-inflammatory phenotype. In contrast, M2 macrophages result from alternative activation of monocyte/macrophages that are induced by exposure to IL-4 and IL-13, and exhibit an anti-inflammatory phenotype that is thought to participate in the resolution of inflammation [27]. According to the M1/M2 para-
Fig. 3. Molecular mechanisms contributing to macrophage fusion. Schematic representation of the process of monocyte/macrophage fusion indicating factors reported to be involved, signaling events and possible roles of NADPH oxidase-generated ROS. A number of fusogenic proteins are involved, including interactions between CD200 and CD200R; CD47 and signal regulatory protein $\alpha(\operatorname{SIRP} \alpha) ; \mathrm{CD} 36$ and phosphatidylserine (PtdS); DCSTAMP and CD44, CD47 (not shown), SIRP $\alpha$ (not shown) and monocyte chemoattractant protein-1 (MCP-1). In addition, $\beta_{1}$ and $\beta_{2}$ integrins play a role in the fusion process by binding to their ligands (example shown is the $\beta_{2}$ ligand CD54 or intercellular adhesion molecule 1 , but there are other potential ligands for these integrins involved in macrophage fusion). Macrophage activation and adhesion of cells to each other leads to membranemembrane interactions. The events causing actual membrane fusion are complex, but may be facilitated by action of $\mathrm{P}_{2} \mathrm{X}_{7}$ receptors, which form membrane pores that would allow cell contents to interconnect. The $\mathrm{d} 2$ isoform of vacuolar ATPase $\mathrm{V}_{0}$ domain (Atp6v0d2) may also contribute to these events by regulating organelle $\mathrm{pH}$ and somehow facilitating fusion (not shown). In addition to extracellular fusion factors, additional intracellular signaling events also are important, including activation of the receptor activator for nuclear factor $\kappa \mathrm{B}$ (RANK) by its ligand (RANKL), which leads to intracellular $\mathrm{Ca}^{2+}$ flux, activation of $\mathrm{c}$ -
Jun N-terminal kinase (JNK) and TNF receptor-associated factor 6 (TRAF-6), and downstream induction of CD200 expression. Activation of TRAF- 6 eventually leads to activation of transcription via nuclear factor $-\kappa \mathrm{B}(\mathrm{NF}-\kappa \mathrm{B})$ and nuclear factor of activated $\mathrm{T}$ cells (NFAT). Note that the RANK/RANKL pathways are specific for osteoclast formation and do not participate in formation of other multinucleated giant cells. Cleavage of activated CD 44 by presenilin 2 (PS2) also contributed to NF- $\mathrm{KB}$ activation via release of CD44 intracellular domain (CD44ID), which moves to the nucleus. NADPH oxidase (Nox)-generated ROS play a role in many of these events by inducing expression of integrins and fusion proteins, inducing RANKL expression in a positive feedback loop, and activating redox-sensitive transcription factors (for example, NF- $\mathrm{B}$ and NFAT). In addition, ligation or activation of fusion factors (such as $\mathrm{P} 2 \mathrm{X}_{7}, \mathrm{CD} 44$ and $\operatorname{SIRP} \alpha$ ) can also induce ROS production, thereby enhancing the positive feedback loop involving ROS (not shown). Intracellular signaling induced by the various ligand-receptor interactions involve additional signaling molecules and transcription factors [activator protein 1 (AP-1), Janus kinase (JAK), Lyn tyrosine kinase, mitogen-activated protein kinases (MAPK), phosphoinositide 3-kinase (PI3K), SH2containing inositol phosphatase (SHIP), and signal transducers and activator of transcription (STAT)], as indicated. See text for further details. 
Table 1. Summary of factors reported to participate in fusion of multinucleated giant cells

\begin{tabular}{|c|c|c|c|}
\hline & $\begin{array}{l}\text { Foreign-body } \\
\text { giant cells }\end{array}$ & $\begin{array}{l}\text { Langhans/im- } \\
\text { mune giant cells }\end{array}$ & $\begin{array}{l}\text { Osteo- } \\
\text { clasts }\end{array}$ \\
\hline \multicolumn{4}{|l|}{ Soluble mediators } \\
\hline GM-CSF & $\mathrm{X}$ & $\mathrm{X}$ & \\
\hline IFN- $\gamma$ & & $\mathrm{X}$ & \\
\hline IL-3 & & $\mathrm{X}$ & \\
\hline IL-4 & $\mathrm{X}$ & & \\
\hline IL-6 & & $\mathrm{X}$ & \\
\hline IL-13 & $\mathrm{X}$ & & \\
\hline MCP-1 & $\mathrm{X}$ & & $\mathrm{X}$ \\
\hline M-CSF & & & $\mathrm{X}$ \\
\hline Muramyl dipeptide & & $\mathrm{X}$ & \\
\hline TNF- $\alpha$ & & & $\mathrm{X}$ \\
\hline Vitamin E & $\mathrm{X}$ & & \\
\hline Vitronectin & $\mathrm{X}$ & & $\mathrm{X}$ \\
\hline \multicolumn{4}{|l|}{ Receptors } \\
\hline$\beta$ Integrins & $\mathrm{X}$ & & $\mathrm{X}$ \\
\hline $\mathrm{CD} 36$ & $\mathrm{X}$ & & \\
\hline CD44 & $\mathrm{X}$ & $\mathrm{X}$ & $\mathrm{X}$ \\
\hline CD200 receptor & & & $\mathrm{X}$ \\
\hline DC-STAMP & $\mathrm{X}$ & & $\mathrm{X}$ \\
\hline Mannose receptor & $\mathrm{X}$ & & \\
\hline RANK & & & $\mathrm{X}$ \\
\hline $\operatorname{SIRP} \alpha$ & $\mathrm{X}$ & & $\mathrm{X}$ \\
\hline Tetraspanins & $\mathrm{X}$ & & $\mathrm{X}$ \\
\hline \multicolumn{4}{|l|}{ Other factors } \\
\hline ATP6V0D2 & $\mathrm{X}$ & & $\mathrm{X}$ \\
\hline CD47 & $\mathrm{X}$ & & $\mathrm{X}$ \\
\hline CD200 & & & $\mathrm{X}$ \\
\hline $\mathrm{P} 2 \mathrm{X}_{7}$ receptor & $\mathrm{X}$ & $\mathrm{X}$ & $\mathrm{X}$ \\
\hline RANKL & & & $\mathrm{X}$ \\
\hline
\end{tabular}

Factors reported to contribute to fusion of the indicated giant cell variants are noted $[6,28]$.

digm, formation of Langhans giant cells, Touton giant cells and osteoclasts results from fusion of M1-polarized macrophages, whereas foreign-body giant cells form from fusion of M2-polarized macrophages. Note, however, that M1 and M2 macrophages actually represent extreme ends of the continuum of macrophage polarization, and the relative level of polarization in the precursors for the various types of multinucleated giant cell precursors may vary. For example, Anderson et al. [28] reported that monocyte/macrophages adherent to biomaterials (precursors to foreign-body giant cells) exhibited a profile that was neither M1 nor M2, but somewhere in between. Furthermore, polarized macrophages can also be repro- grammed. For example, macrophage reprogramming from an M1 to an M2 phenotype is associated with chronic or persistent infectious diseases [reviewed in 26]. Thus, M2-polarized macrophages are likely to be involved in the formation of Langhans giant cells during chronic phases of mycobacterial infection.

\section{Dendritic Cell-Specific Transmembrane Protein}

Dendritic cell-specific transmembrane protein (DCSTAMP) is a membrane receptor that has been shown to be required for fusion of osteoclasts and foreign-body giant cells; however, the signaling pathways involved seem to be distinct in these two types of multinucleated giant cells [29]. For example, c-Fos and NFAT are both required for DC-STAMP expression and cell-cell fusion in osteoclasts, whereas these factors are not essential for giant cell formation [29]. On the other hand, the myeloid-specific transcription factors PU.1 and NF- $\kappa \mathrm{B}$ appear to be involved in regulating DC-STAMP expression in foreignbody giant cell formation induced by GM-CSF and IL- 4 [29]. Thus, such differences in regulatory signaling pathways seem to facilitate formation of the distinct types of multinucleated macrophages. Currently, the ligand for DC-STAMP involved in cell-cell fusion is not known. Since DC-STAMP shares structural similarity with chemokine receptors, it has been suggested that a chemokine could be a potential ligand. Monocyte chemoattractant protein-1 (MCP-1) is one such chemokine, and it has been shown that expression of MCP-1 is induced by RANKL [30]. MCP-1 can promote osteoclast fusion, and the formation of foreign-body giant cells is compromised in MCP1-deficient animals [31]. Additional candidate ligands that have been proposed for DC-STAMP include signal-regulatory protein $\alpha$ (SIRP $\alpha$; also known as macrophage fusion receptor), CD47 and CD44 [reviewed in 2].

\section{$\operatorname{SIRP} \alpha$}

SIRP $\alpha$ is a transmembrane protein belonging to the immunoglobulin superfamily of proteins and is expressed primarily on myeloid cells [reviewed in 32]. CD47 is a ligand for SIRP $\alpha$, and CD47-SIRP $\alpha$ interactions can mediate cell-cell adhesion events [33] (fig. 3). Indeed, Han et al. [34] reported that CD47 expression was induced at the onset of macrophage fusion and contributed to multinucleated giant cell formation via its interaction with SIRP $\alpha$ during cell fusion.

\section{$\beta$ Integrins}

$\beta$ Integrins play important roles in mediating cell-cell and cell-extracellular matrix adhesive interactions [re- 
viewed in 35], and McNally et al. [36] demonstrated that $\beta_{1}$ and $\beta_{2}$ integrins participate in macrophage-macrophage adhesion during IL-4-induced foreign-body giant cell formation. Both types of integrins were highly upregulated on fusing macrophages, and antibodies against these integrins inhibited fusion. Subsequently, this group reported that the specific integrin subtypes involved in fusion included $\alpha_{M} \beta_{2}, \alpha_{X} \beta_{2}, \alpha_{5} \beta_{1}, \alpha_{V} \beta_{1}, \alpha_{2} \beta_{1}$ and $\alpha_{3} \beta_{1}$ [37]. In addition, Rao et al. [38] reported that $\alpha_{9} \beta_{1}$ participated in macrophage fusion during osteoclast formation.

\section{CD36}

CD36 is a member of the scavenger receptor family and binds to a wide range of ligands [39]. Recently, Helming et al. [17] showed that CD36 is also involved in macrophage fusion and giant cell formation induced by GMCSF and IL-4. Furthermore, their studies indicated that localized areas of exposed phosphatidylserine were recognized by CD36, implicating this interaction in the fusion process [17] (fig. 3). Note, however, that CD36 was not sufficient for macrophage fusion and additional IL4 -inducible factors were required.

\section{CD44}

CD44 is an integral membrane glycoprotein that plays an important role in cell-cell and cell-substrate adhesive interactions [reviewed in 40]. Sterling et al. [41] reported that expression of CD44 was significantly, but transiently induced on macrophages exposed to fusogenic conditions and that addition of CD44 ligands interfered with macrophage multinucleation. More recently, this group found that the intracellular domain of CD44 (CD44ICD) is cleaved in macrophages undergoing fusion, CD44ICD promotes the fusion of macrophages, and CD44ICD localizes to the nucleus of macrophages and induces NF- $\kappa \mathrm{B}$ activation (fig. 3). In addition, they found that presenilin 2 (PS2) expression is also induced at the onset of fusion, and that inhibitors of PS prevented macrophage fusion and formation of CD44ICD [42]. Thus, PS2-mediated cleavage of CD44 represents an important mechanism contributing to macrophage fusion and multinucleation.

\section{CD200}

CD200 is a member of the immunoglobulin superfamily of proteins and is expressed on a variety of cells, although not normally on myeloid cells, whereas its receptor (CD200R) is expressed predominantly in myeloid cells [43]. Recently, Cui et al. [44] showed that CD200 expression was significantly induced at the onset of macro- phage fusion and that multinucleation was defective in CD200-deficient osteoclasts due to interruption of signaling downstream of RANK (fig. 3). Thus, these studies suggest that CD200 also plays a central role in macrophage fusion and osteoclast formation.

\section{d2 Isoform of Vacuolar ATPase $V_{0}$ Domain (ATP6V0D2)}

The vacuolar type $\mathrm{H}^{+}$-ATPase (V-ATPase) is a ubiquitously expressed enzyme complex that plays a role in acidification of a wide array of intracellular organelles. Multiple isoforms of some V-ATPase subunits have been identified, including two isoforms of the $\mathrm{V}_{0}$ subunit (designated as ATP6V0D1 and ATP6V0D2). Lee et al. [45] showed that Atp6v0d2-deficient mice exhibited osteopetrosis and that this was due to diminished osteoclast fusion. They concluded that Atp6v0d2 serves as a regulator of macrophage fusion, but also showed that this regulation did not involve DC-STAMP, RANK or NFAT. More recently, $\mathrm{Wu}$ et al. [46] confirmed this conclusion by showing that RNA interference knockdown of Atp6v0d2 in murine bone marrow macrophages not only impaired osteoclast multinucleation but also interfered with the extracellular acidification required for bone resorption by murine osteoclasts.

\section{Purinergic Receptor $\mathrm{P}_{2} \mathrm{X}_{7}$}

The $\mathrm{P} 2 \mathrm{X}_{7}$ receptor is an ATP-gated ion channel that is expressed on a variety of cells, including macrophages [reviewed in 47]. Activation of $\mathrm{P}_{2} \mathrm{X}_{7}$ receptors by ATP leads to the reversible formation of membrane pores that are permeable to large molecules [48] (fig. 3). However, long-term activation leads to ATP-dependent lysis of macrophages through the formation of membrane pores permeable to large molecules [47]. Interestingly, it has been shown that $\mathrm{P} 2 \mathrm{X}_{7}$ receptors contribute to the process of macrophage fusion during the formation of multinucleated giant cells [49]. Indeed, the $\mathrm{P}_{2} \mathrm{X}_{7}$ receptor has been reported to participate in the formation of all main types of multinucleated giant cells and is proposed to represent a common molecular feature required for macrophage fusion [reviewed in 6].

\section{Role of ROS in Macrophage Fusion}

Although ROS are known to participate in macrophage multinucleation, the mechanisms involved are not well defined. Note that many factors reported to participate in macrophage fusion are also known to modulate 
Table 2. Effect of giant cell fusion factors on monocyte/macrophage ROS production

\begin{tabular}{ll}
\hline Factor/receptor & Effect on ROS production \\
\hline BzATP/P2X & $\uparrow$ \\
Hyaluronic acid/CD44 & $\uparrow$ \\
CD47/SIRP $\alpha$ & $\uparrow$ \\
GM-CSF/GM-CSF receptor & $\uparrow$ \\
IL-4/IL-4 receptor & $\downarrow$ \\
LPS/Toll-like receptor 4 & $\uparrow$ \\
MCP-1/CCR2 & $\uparrow$ \\
M-CSF/M-CSF receptor & $\uparrow$ \\
Phosphatidylserine/CD36 & $\uparrow$ \\
RANK/RANKL & $\uparrow$ \\
TNF- $\alpha /$ TNF- $\alpha$ receptor & $\uparrow$ \\
\hline
\end{tabular}

ROS production in monocyte/macrophages (fig. 3, table 2), which could participate in the fusion process. For example, addition of exogenous $\mathrm{H}_{2} \mathrm{O}_{2}$ to bone marrowderived monocyte/macrophages or osteoclast precursor HD-11EM cells has been shown to enhance macrophage fusion and osteoclast formation [50-52]. Furthermore, the formation of osteoclasts from murine bone marrowderived monocyte/macrophages can be suppressed by addition of catalase, which metabolizes $\mathrm{H}_{2} \mathrm{O}_{2}$ [50]. Likewise, Kyung et al. [53] recently reported that rutin, an ROS scavenger, inhibited osteoclast formation in bone marrow-derived macrophages treated with M-CSF and RANKL. Finally, Lee et al. [54] found that inhibition of RANKL-mediated ROS production with a dominant-interfering mutant of TNF receptor-associated factor 6 (TRAF6), treatment with an ROS scavenger (N-acetylcysteine) or NADPH oxidase inhibitor (diphenylene iodonium), or interfering with NADPH oxidase activity by depleting NOX1 using RNA interference or expressing a dominant-negative mutant of Racl all blocked osteoclast differentiation, suggesting that ROS act as an intracellular signal mediator for osteoclast differentiation. Thus, it is clear that ROS play regulatory roles in osteoclast fusion and multinucleation of other cells; however, the function of ROS in the formation of foreign-body giant cells or Langhans giant cells still remains to be determined.

Although the exact mechanisms involved in ROS regulation of macrophage fusion have not been established, several possible pathways have been implicated. For example, $\mathrm{ROS}\left(\mathrm{H}_{2} \mathrm{O}_{2}\right.$ or $\left.\mathrm{O}_{2}\right)$ have been reported to stimulate RANKL expression in murine osteoblasts and human osteoblast-like MG63 cells, which enhanced osteoclast formation [55]. This process was mediated by activation of extracellular signal-regulated kinase and cAMP response element-binding protein in murine cells and extracellular signal-regulated kinase and heat shock factor 2 in human cells [55]. As indicated above, Rac GTPases play important roles in osteoclast differentiation, which is due in part to their role in NADPH oxidase function. Recently, Wang et al. [56] evaluated osteoclastogenesis in Rac1- and Rac2-deficient mice and found that while Racl and Rac2 play different and nonoverlapping roles in osteoclastogenesis, Racl was the primary Rac isoform responsible for regulating ROS generation and the actin cytoskeleton during the various stages of osteoclast differentiation. In addition, ROS induce expression of $\beta$ integrins and their ligands $[57,58]$, which also contribute to fusion events [36].

As discussed above, studies with RANKL- or RANKdeficient mice indicate that the RANKL/RANK pathway is required for osteoclast multinucleation [reviewed in 24]. Thus, it is difficult to explain the mechanisms behind the RANKL-independent systems that have been reported. One suggestion is that these inflammatory signals obviate the need for RANK by directly activating the NF- $\kappa B$ pathway, which would lead to multinucleation when the right combination of additional signals is present. One of these signals may be the local presence of ROS, since both NF- $\kappa B$ and NFAT are oxidative stress-responsive transcription factors [59]. Indeed, it is well known that ROS alone or in cooperation with cytokines, such as TNF- $\alpha$, can activate NF- $\kappa \mathrm{B}$ and subsequent downstream signaling cascades [60].

Lipid capture by cell surface receptors may be a general feature of cell fusion, and Helming et al. [17] showed that macrophages display localized areas of phosphatidylserine on the cell surface and that lipid recognition by CD36 is required for efficient fusion of macrophages treated with GM-CSF and IL-4. Note that CD36 activation also leads to the induction of ROS production and MCP-1 and membrane lipid rafts are ordered structures of membrane microdomains enriched in cholesterol, glycosphingolipids and glycosylphosphatidylinositol-anchored proteins [reviewed in 61]. Interestingly, lipid raft expression has been shown to increase during osteoclast formation, and TRAF- 6 is recruited to osteoclast lipid rafts during RANKL stimulation [62]. Furthermore, Ishii et al. [63] reported that RANKL-induced expression of CD9, a member of the tetraspanin superfamily proteins, in lipid rafts was required for macrophage fusion during osteoclast formation. While there are no reports investigating the role of ROS in lipid raft function during macrophage multinucleation, it is a reasonable possibility 
based on studies showing that lipid rafts can serve as a scaffold for NADPH oxidase assembly [64] and that ROS promote lipid raft formation [65].

\section{ROS Production and NADPH Oxidase Expression in Multinucleated Giant Cells}

Multinucleated giant cells arise from macrophage precursors and, although their differentiation modulates the unique range of enzymes that are expressed, these cells also retain some characteristics of mononucleated macrophages. Based on their cellular origin, it is not surprising that the various types of multinucleated giant cells have been shown to generate ROS, as ROS production is one of the hallmarks of all professional phagocytes, including neutrophils and monocyte/macrophages [reviewed in 66]. Among the multinucleated giant cells known to generate ROS are osteoclasts $[67,68]$ and multinucleated giant cells of noninfectious and infectious granulomas [69-71]. Note, however, that multinucleated giant cells generally exhibit an enhanced ROS-generating capacity (20- to 30-fold) compared with unfused macrophages [69].

The source of ROS generated by multinucleated giant cells has been investigated by a number of groups, and most studies suggest that NADPH oxidases are among the primary systems responsible for $\mathrm{O}_{2}^{\overline{2}}$ production $[67$, 71-75]. The phagocyte NADPH oxidase is a multiprotein enzyme complex that plays an essential role in innate immunity [reviewed in 66]. It is composed of a plasma membrane-associated flavocytochrome $b$, which is comprised of gp91 ${ }^{\text {phox }}$ (now known as NOX2) and p22 phox , and $4 \mathrm{cy}$ tosolic proteins (p40 phox $, \mathrm{p} 47^{\text {phox }}, \mathrm{p} 67^{\text {phox }}$ and Rac2), and catalyzes the transfer of electrons from NADPH to $\mathrm{O}_{2}$, resulting in the formation of $\mathrm{O}_{2}^{\overline{2}}$ and other $\mathrm{ROS}$ important for defense against microbial pathogens [reviewed in 76]. Originally, it was thought the NADPH oxidase was specific to phagocytic cells; however, subsequent studies revealed the presence of analogous systems and homologous proteins in nonphagocyte tissues [reviewed in 76]. These enzymes are functionally distinct from the phagocyte NADPH oxidase and can be distinguished by their unique NOX2 homolog. Currently, there are 6 such homologs, designated as NOX1, NOX3, NOX4, NOX5, DUOX1 and DUOX2 [77]. The various NOX proteins are homologous in size and domain structure to NOX2; however, their patterns of tissue expression are distinct [reviewed in 76].
Although monocyte/macrophages and neutrophils express the same phagocyte NADPH oxidase components, NADPH oxidase activity seems to be regulated differently in these cell types [59]. For example, monocytes show a gradual increase in $\mathrm{O}_{2}$ production after stimulation with soluble agonists [78], whereas the response in neutrophils is much faster [79]. In addition, the monocyte oxidase can be reactivated after sufficient recovery, which is typically not the case for neutrophils [80]. Finally, different types of stimuli can activate the monocyte/macrophage and neutrophil NADPH oxidases [reviewed in 59, 81]. Thus, differences in NADPH oxidase regulation have been proposed to contribute to the distinct roles of monocyte/macrophages and neutrophils in chronic versus acute inflammation, respectively [82], and some of these differences may be important in the formation and function of multinucleated giant cells. Previously, we found that the genes encoding NOX2, p4 $7^{\text {phox }}$ and p6 $7^{\text {phox }}$ were induced in TNF- $\alpha$-treated monocyte/macrophages via activation of NF- $\kappa$, resulting in increased NADPH oxidase protein expression and activity [83]. Based on these studies, we proposed that a positive feedback mechanism may exist, whereby NF- $\kappa$ B activation leads to upregulation of NADPH oxidase expression and subsequent $\mathrm{O}_{\overline{2}}^{\overline{2}}$ production, which in turn can further activate NF- $\kappa B$ in the same cells (autocrine) and neighboring phagocytes (paracrine). As a consequence, this positive feedback loop would result in sustained production of $\mathrm{O}_{2}^{-}$and contribute to the pathogenesis of chronic inflammatory diseases. Given the intricate relationship between NF- $\kappa \mathrm{B}$ and $\mathrm{O}_{2}^{-}$ in chronic inflammation, establishing the pathways that regulate the NADPH oxidase activity in multinucleated giant cells may eventually help to identify critical events associated with disease pathogenesis.

The level of Nox 2 expressed in murine osteoclasts is almost double of that in phagocytes, suggesting that the NADPH oxidase complex is highly expressed in osteoclasts [72], which may explain the higher levels of $\mathrm{O}_{2}$ generated by these cells $[68,84,85]$. $\mathrm{O}_{\dot{2}}^{-}$has been detected at the ruffled border of osteoclasts, which suggests that ROS are produced at sites of resorption and may participate in matrix degradation. Interestingly, it has been observed that osteoclasts from Nox2-deficient mice still produce similar levels of $\mathrm{O}_{\overline{2}}^{\overline{2}}$, and Yang et al. [73] demonstrated that this activity was due to the presence of Nox 4 in these cells. Subsequently, this group reported that Nox4 was upregulated during osteoclast differentiation [74]. Thus, a NOX2 to NOX4 transition may be one of the important features of osteoclasts. NOX4 requires p22 $2^{\text {phox }}$ but does not require the additional cytosolic cofactors that are essential 
for the NOX2-based NADPH oxidase [86]. In addition, the NOX4/p22 phox system produces large amounts of $\mathrm{H}_{2} \mathrm{O}_{2}$ that are released extracellularly [86]. These features of NOX4 are consistent with the functional requirement for ROS in bone resorption $[84,87]$. Note that NOX1 has also been proposed to play a role in osteoclast differentiation, and depletion of NOX1 by RNA interference was found to block osteoclast differentiation [54]. Liberman et al. [75] recently reported that macrophage foam cells produced higher levels of ROS at sites of aortic valve calcification (rabbit or human) and proposed this may reflect ROS signaling in cellular processes, including the formation of multinucleated giant cells. These cells exhibited increased expression of NADPH oxidase subunits NOX2 and p22 phox, as well as increased message for NOX4, but not NOX1 [75]. Interestingly, NOX4 has been reported to have an anti-apoptotic effect [88], and this property could possibly contribute to the persistence of multinucleated giant cells in inflammatory diseases.

Whether NOX1 and NOX4 play a role in the function of other multinucleated giant cells remains to be determined, as expression of NOX1 and NOX4 in foreign-body or immune giant cells has not been reported. This is an especially important question in relation to chronic granulomatous disease (CGD). CGD is a rare genetic disease caused by defects in NOX2, p22 phox, p $47^{\text {phox }}$ or p67phox, and results in an inactive NADPH oxidase [recently reviewed in 89]. As a result, patients with CGD experience severe, recurrent bacterial and fungal infections and develop granulomas, which are characterized by the presence of multinucleated giant cells [90, 91]. CGD is characterized by excessive inflammation, which is thought to be due to several factors that result from loss of NADPH oxidase activity, including the persistence of pathogens due to defective phagocyte killing, excessive generation of IL-8 by CGD neutrophils, and delayed apoptosis of CGD neutrophils [reviewed in 92]. Although neutrophils from CGD patients are unable to generate ROS, they are still able to kill a number of pathogens, presumably through the action of other phagocyte antimicrobial components, and Kobayashi et al. [93] showed that neutrophils from individuals with CGD have increased levels of transcripts encoding proteins that participate in host defense. Thus, it is clear that compensatory microbicidal mechanisms do exist in phagocytes from patients with CGD. If ROS are indeed important or necessary for macrophage multinucleation and the formation of osteoclasts and foreign-body giant cells, which are present in individuals with CGD, then compensation must be provided by other ROS-generating systems, such as NOX1- and
NOX4-based NADPH oxidases and possibly xanthine oxidase. Not much is known regarding the expression of NOX2 homologs in CGD. Baniulis et al. [94] reported that NOX1, NOX3 and NOX4 were not expressed in neutrophils obtained from CGD patients. However, expression of these proteins in monocyte/macrophages or giant cells was not evaluated. Thus, it will be interesting to evaluate this issue in the future, given that Nox4, and perhaps Nox1, appears to compensate for Nox 2 in osteoclasts from murine models of CGD. Likewise, the role of xanthine oxidase in the formation or function of giant cells also needs further investigation. Segal et al. [95] showed that xanthine oxidase could contribute to host defense in a murine model of autosomal CGD and thus partially compensate for loss of phagocyte NADPH oxidase activity. Interestingly, Mizuno et al. [96] reported that the xanthine oxidase inhibitor, allopurinol, inhibited the formation of multinucleated giant cells from human monocytes, partly through the downregulation of intercellular adhesion molecule- 1 and $\mathrm{P}_{2} \mathrm{X}_{7}$. As discussed above, $\mathrm{P} 2 \mathrm{X}_{7}$ plays an important role in the fusion process leading to macrophage multinucleation. Although there are no reports regarding a link between NADPH oxidase activity and $\mathrm{P} 2 \mathrm{X}_{7}$ in macrophage fusion, stimulation of $\mathrm{P} 2 \mathrm{X}_{7}$ has been reported to enhance NADPH oxidase activity in human monocytes [97]. This group also showed that ATP stimulation of THP-1 monocytes enhanced translocation of $\mathrm{p} 47^{\text {phox }}$ with $\mathrm{p} 67^{\text {phox }}$ to the membranes where oxidase assembly occurs and that this process was blocked by a $\mathrm{P}_{2} \mathrm{X}_{7}$ receptor antagonist [97]. Likewise, ligation of CD44 or SIRP $\alpha$ has also been reported to induce NADPH oxidase-dependent ROS production [98, 99]. Based on these observations, it is possible that fusogenic events leading to activation of $\mathrm{P} 2 \mathrm{X}_{7}, \mathrm{CD} 44$ and SIRP $\alpha$ could enhance NADPH oxidase assembly and ROS production in macrophage membranes, thereby contributing to cell fusion.

In addition to NOX-based enzymes, osteoclasts and activated macrophages also express tartrate-resistant acid phosphatase (TRACP), which contains a binuclear iron center and can also generate ROS [100]. ROS generated by TRACP have been reported to participate in bone matrix degradation, degradation of foreign material during antigen presentation, and bacterial killing [101]. Interestingly, Halleen et al. $[100,102]$ reported that TRACP colocalized in macrophage compartments containing phagocytosed Staphylococcus aureus and that macrophages from TRACP-overexpressing mice exhibited increased bacterial killing capacity. Thus, TRACP seems to be an important component of macrophage function by generating intracellular ROS which could be targeted to 
destroy phagocytosed pathogens and/or foreign material. It is reasonable to suggest that NADPH oxidase and TRACP represent complementary mechanisms utilized by mononucleated and multinucleated macrophages.

\section{Role of Multinucleated Giant Cells in Inflammation and Autoimmune Diseases}

Giant cells are one of the characteristic features of granulomas and play an important role in regulating granuloma formation by generating cytokines and other mediators [103]. Macrophage fusion results in the formation of cells large enough to resorb or sequester extracellular material, such as bone and foreign bodies $[2,6]$. In addition, macrophages may also be able to fuse with somatic cells during tissue repair or with tumor cells, thereby contributing to metastasis [104]. Here, we briefly describe the involvement of multinucleated giant cells and the potential role of NADPH oxidases in some of these inflammatory processes.

\section{Immune Granulomas}

Granulomas are organized collections of mononuclear phagocytes formed in a ball-like structure with the goal of destroying or isolating foreign substances [reviewed in 105]. Thus, granulomas represent a specialized inflammatory reaction that is common to a number of diseases. The formation of granulomas can represent a specific, inflammatory response induced by a pathogen (immune or infectious granuloma) or can represent the containment and possible degradation of a foreign particle or substance (nonimmune or noninfectious granuloma) $[105,106]$. Granulomatous inflammation is highly effective in destroying many pathogens; however, some pathogens can avoid destruction, such as facultative or obligate intracellular organisms, and they become sequestered in mature granulomas. Furthermore, multinucleated giant cells are present in immune granulomas formed in association with a number of infectious diseases, including tuberculosis [71], brucellosis [107], aspergillosis [108], cryptococcosis [109], leprosy [110] and others (see fig. 2a).

It is thought that immune granulomas play an important role in control of bacterial growth and dissemination [111]. For example, tuberculosis-associated Langhans giant cells have been found to restrict cell-to-cell spread of mycobacteria [112]. One of the distinguishing features of immune granulomas is the presence of T cells, and these lymphocytes are found surrounding and in close contact with the aggregate of macrophages and multinucleated giant cells [113]. Note, however, that recent studies in $\mathrm{T}$ cell-deficient mice suggest that $\mathrm{T}$ cells are not absolutely required for the foreign-body giant cell formation and that compensatory pathways can be invoked [114]. Granuloma-associated T lymphocytes appear to be sensitized to microbial antigens, altered cellular structure or damaged basement membrane/matrix, resulting in the generation of cytokines that recruit and activate additional macrophages, as well as promote macrophage fusion [1]. In addition to leukocyte-derived innate immune mediators, pathogen-derived products also appear to participate in macrophage fusion. For example, Okamoto and coworkers $[115,116]$ reported that muramyl dipeptide, a peptidoglycan portion of bacterial cell walls, acted in concert with inflammatory cytokines to induce Langhans cell formation, possibly involving $\mathrm{P}_{2} \mathrm{X}_{7}$ receptors in the fusion process. Furthermore, Lay et al. [71] reported that high-virulence mycobacterium (Mycobacterium tuberculosis) induced large multinucleated giant cells with $>15$ nuclei per cell, whereas multinucleated giant cells formed in response to low-virulence mycobacterium species (M. avium and M. smegmatis) had fewer nuclei per cell $(<7)$ and did not progress to become giant cells. Note, however, that both types of multinucleated cells expressed NADPH oxidase activity [71]. In addition, multinucleated giant cells in tuberculin granulomas also have been shown to accumulate nitrotyrosine, indicating formation of both $\mathrm{O}_{\dot{2}}^{\overline{1}}$ and NO in these lesions [117]. Thus, it is clear that NADPH oxidase-dependent ROS production is important in the function of multinucleated giant cells associated with immune granulomas. Likewise, phagocytegenerated ROS are important inflammatory mediators in many other granulomatous diseases [118, 119], although the role of ROS produced by multinucleated giant cells is not well understood in these cases.

As described above, phagocytes from individuals with CGD lack NOX2-based NADPH oxidase activity [reviewed in 89]. Thus, the question arises as to the potential sources of ROS and/or their role in macrophage fusion and granuloma formation associated with this disease. In addition to the possible contributions of other NOX systems and xanthine oxidase described above, it is also possible that pathogen-derived ROS may at least partially substitute for the loss of the NOX2-based oxidase, thereby providing a source of ROS. Indeed, it has been proposed that the microbicidal capacity of CGD phagocytes depends, to some degree, on $\mathrm{H}_{2} \mathrm{O}_{2}$ produced by the pathogen itself, and that this explains why catalase-positive organisms cause many of the infections in CGD patients 
(such as Aspergillus spp. or Staphylococcus spp.), while catalase-negative organisms rarely infect these individuals [120]. Note, however, that this paradigm is not absolute, and other host- or pathogen-specific factors must also be involved [121]. Interestingly, the incidence of infection in patients with CGD has been shown to be decreased by prolonged treatment with IFN- $\gamma$, although this treatment did not improve NADPH oxidase activity [122]. Given that this cytokine plays an important role in macrophage fusion to form giant cells, one might speculate that part of the benefit could be due to enhanced formation of multinucleated giant cells to improve containment of persistent pathogens.

\section{Nonimmune Foreign-Body Granulomas}

In an effort to isolate foreign material from the host, foreign-body giant cells surround these materials and either dispose of them or sequester them if they cannot be destroyed. For example, foreign-body giant cells sequester various inorganic particles, such as metals $(\mathrm{Co}, \mathrm{Al}, \mathrm{Ba}$, $\mathrm{Be}, \mathrm{Zn}$ ) and minerals (talc, asbestos), as well as aggregates of endogenous substances, such as uric acid, keratin, hemosiderin and insoluble fat deposits [123]. The formation of foreign-body giant cells may also be the result of responses to antigenic structures developed as a result of interaction between self-macromolecules and the surfaces of implanted material and/or the charge characteristics of such foreign surfaces. Macrophages adherent to surfaces of endoprostheses or implanted biomaterials often fuse to form foreign-body giant cells, which are believed to be primary cellular mediators of the chronic inflammatory response to foreign materials [reviewed in 28]. In addition, the type of material present in the granuloma and macrophage inflammatory status also have been shown to be key factors involved in macrophage fusion $[1,124]$. Anderson and Jones [124] found that hydrophobic surfaces on foreign biomaterials supported macrophage adhesion and fusion, whereas hydrophilic/neutral surfaces inhibit adhesion and fusion. Clearly, the ability to adhere also had significant effects on macrophage activation, cytokine production and fusion. For example, vitronectin and E-cadherin have been shown to be important in adhesion events during IL-4-induced foreignbody giant cell formation $[125,126]$.

Currently, the role of ROS in degradation of foreign material is an area of intensive investigation, as prolonged inflammation and ROS generation by macrophages, foreign-body giant cells and osteoclast-like cells around implanted biomaterial is one of the main causes of the foreign-body response [reviewed in 28]. Over time, wear of the implants generates particles capable of activating macrophages and giant cells, resulting in the release of ROS and reactive nitrogen species that contribute to bone resorption and aseptic loosening of implants $[127,128]$. In addition, ROS may attack biomaterials directly and enhance their degradation [129]. Thus, to decrease the impact of ROS on biomaterials, various approaches have been suggested, including protection of the implanted material by addition of antioxidants [130], surface-bound superoxide dismutase mimetics [131], titanium oxide coatings [132] or fluorpolymer surface modifications [133] to the biomaterials.

\section{Sarcoidosis}

Sarcoidosis is a multisystem, autoimmune granulomatous disease that affects the pulmonary, cutaneous and lymphatic systems [reviewed in 134]. Sarcoidosis consists of multi-organ granulomas comprised of macrophages, epithelioid cells and multinucleated giant cells, although there may also be lymphocytes and fibroblasts [135]. The pathogenesis of sarcoidosis involves inflammatory cytokines, such as IL- 6 and TNF- $\alpha$, and the primary treatment is corticosteroids [134]. Recently, TNF- $\alpha$ inhibitors have been used to successfully treat this disease [134]. Note, however, that anti-TNF- $\alpha$ therapy has also been implicated in the development of drug-induced sarcoidosis. In addition, tuberculosis can apparently mimic [136] or coexist with sarcoidosis [137], therefore, making anti-TNF- $\alpha$ treatment problematic in some patients.

The role of ROS in sarcoidosis is not well defined, although it is clear that increased phagocyte ROS production is associated with this disease [138]. Macrophages from patients with sarcoidosis exhibited increased expression of $\beta_{2}$ integrins, which correlated with increased NADPH oxidase activity [138]. As described above, monocyte/macrophage fusion involves a number of fusion proteins, and monocytes from sarcoidosis patients expressed higher levels of $\mathrm{P} 2 \mathrm{X}_{7}$ receptors and fused more readily than those from healthy controls [116]. Furthermore, pharmacological agents that affect sarcoidosis, such as tranilast, allopurinol and captopril, inhibited giant cell formation in vitro by inhibiting the expression of adhesion proteins and $\mathrm{P} 2 \mathrm{X}_{7}$ receptors. Since activation of $\mathrm{P}_{2} \mathrm{X}_{7}$ may enhance monocyte/macrophage NADPH oxidase assembly and ROS production, this could represent a feedback mechanism that facilitates macrophage fusion and further ROS production in sarcoidosis. 


\section{Rheumatoid Diseases}

Multinucleated giant cells have been reported to play a role in the pathogenesis of some rheumatoid diseases, such as rheumatoid arthritis and rheumatic heart disease. Multinucleated giant cells are commonly present in inflamed synovium, often in close association with the intimal layer, and Wilkinson et al. [139] found that two types of multinucleated cells were present in synovial tissue from patients with rheumatoid arthritis, one related to synoviocytes and one derived from macrophages. In addition, the latter cells exhibited osteoclast markers and characteristics. Weinberg et al. [140] showed that synovial tissue from patients with rheumatoid arthritis contained higher numbers of cells than healthy tissue, including many macrophages and multinucleated giant cells, and these cells also produced higher levels of TNF$\alpha$ and IL-1 in vitro. Further analysis of the nature of these cells showed that the multinucleated bone-resorbing giant cells in synovial fluids of patients with rheumatoid arthritis were indeed osteoclasts and that the fusion index and bone-resorption functions of these cells were enhanced significantly in patients with rheumatoid arthritis [141]. Furthermore, synovial pannus tissue is characterized by high levels of RANKL versus osteoprotegrin, which is proposed to favor local generation of bone-resorbing osteoclasts at the site of erosion in rheumatoid arthritis [142].

ROS likely play a number of roles in the pathogenesis of rheumatoid arthritis. As described above, osteoclasts generate significant levels of ROS, and NOX2 and/or NOX4 is localized in their ruffled membranes, such that ROS are generated at the sites of bone resorption and matrix degradation $[67,74]$. Furthermore, phagocytes, and possibly multinucleated giant cells, from patients with arthritis have a significantly increased ability to produce ROS, and this phenomenon has been attributed in part to priming by TNF- $\alpha$ [143]. Pharmacological agents that destroy or inhibit the production of ROS, such as apocynin [144], methotrexate [145], or diphenylene iodonium [146], can suppress the development of inflammation and symptoms associated with arthritis. On the other hand, joint inflammation and bone erosion are worse in $\mathrm{p} 47^{\text {phox }}$ and Nox2-deficient CGD mice with experimentally induced arthritis, and the authors concluded that ROS might actually play a role in limiting the disease process under certain conditions [147]. Olofsson and coworkers $[148,149]$ reported that a polymorphism of the gene encoding $\mathrm{p} 47^{\text {phox }}$ (NCF1) regulates the severity of arthritis and proposed NADPH oxidase-derived ROS reduced arthritis by regulating arthritogenic $\mathrm{T}$ cells. Thus, it may be that under healthy conditions, ROS work to prevent arthritis and other autoimmune conditions, whereas, once these conditions develop, oxidants can contribute directly to pathogenesis. Since $\mathrm{p} 47^{\text {phox }}$ is expressed in osteoclasts as well, additional mechanisms of ROS-dependent regulation may be involved at the level of these cells; however, further research in this area is needed.

Rheumatic fever is an important cause of cardiac injury worldwide [reviewed in 150]. Rheumatic fever is characterized by a nonspecific myocarditis, as well as lesions containing granulomas known as Aschoff nodules [151]. In rheumatic Aschoff nodules, a central necrotic focus is surrounded by immune giant cells and lymphocytes, and these cells have been shown to participate in the resorption of necrotic and fibrous tissue of rheumatoid nodules [152]. Fraser et al. [153] proposed that these lesions exhibit progressive phases, with the early phases characterized by macrophage influx and production of IL- 1 and TNF- $\alpha$, followed by later stages of T and B cell recruitment and activation, as well as IL-2 production. The recruitment and activation of macrophages, as well as the formation of multinucleated giant cells, suggests that NADPH oxidase assembly and ROS production would be a prominent feature of this lesion that could participate in tissue resorption and repair; however, the actual role of ROS in this pathologic process has not been evaluated.

\section{Giant Cell Arteritis}

Giant cell arteritis (GCA) is an innate immune disease of medium to large blood vessels and is most often associated with vasculature in the head [reviewed in 154]. GCA is the most common primary vasculitis in the West and affects older adults (average age of 75) [155]. The pathogenesis of GCA typically appears to involve two processes, an acute-phase systemic innate response and an antigen-dependent immune response directed against arterial wall components [154]. GCA is characterized histologically by inflammatory infiltrates that penetrate through all layers of the vessel wall. These infiltrates are comprised primarily of highly activated monocyte/macrophages and $\mathrm{CD} 4^{+} \mathrm{T}$ cells and can include granulomas that tend to form in the arterial media near the internal elastic lamina [155]. In approximately $50 \%$ of the cases, multinucleated giant cells are present [154]. Activation of adventitial $\mathrm{CD}^{+}{ }^{+} \mathrm{T}$ cells results in production of IFN- $\gamma$, which regulates the differentiation and function of recruited macrophages and likely contributes to macrophage multinucleation [156]. While it is accepted that GCA is a T cell-dependent, Th1-driven 
disease [157], the antigens involved are not well defined and may be foreign or host derived. Analysis of GCA lesions indicated the association of foreign-body giant cells with calcified regions of the internal elastic lamina [158]. However, some lesions also contain Langhans giant cells, suggesting the possibility that infection may also contribute to the pathogenesis of this disease in some cases [159]. Additionally, some multinucleated giant cells stain positive for the myeloid-related protein S100, suggesting that dendritic cells may contribute to macrophage fusion during giant cell formation [160]. It is also possible that giant cells could be formed through fusion of dendritic cells, which would be promoted by IFN- $\gamma$ [161]. Indeed, concentrations of tissue IFN- $\gamma$ correlate with the formation of multinucleated giant cells in GCA [162].

The tissue injury associated with GCA appears to be mediated by products of macrophage activation, including ROS and matrix metalloproteinases [70, 163], which can damage the internal elastic lamina and contribute to giant cell formation [164]. In addition, peptides generated during elastin hydrolysis can serve as autoimmune targets for the T cells [165], and it has been reported that adventitial $\mathrm{CD} 4^{+} \mathrm{T}$ cells can undergo clonal expansion in the adventitia and that adventitial dendritic cells play a key role in this process by serving as antigen-presenting cells $[160,162]$.

While it is clear that ROS generated by multinucleated giant cells and macrophages play a key role in the pathogenesis of GCA [70], the enzymatic sources are not well defined. Based on the NOX protein expression described above, it is reasonable to suggest that both NOX2- and NOX4-based systems could be involved. In support of this idea, S100A8 (myeloid-related protein-8) and S100A9 (myeloid-related protein-14) are expressed in human GCA, colocalized with areas of vascular calcification [166], which is also the location of giant cell formation. These proteins are highly expressed in myeloid cells [167] and have been shown to play a role in NADPH oxidase activation by interacting with p67phox and Rac2 during oxidase activation and facilitating enzyme assembly [168]. Nevertheless, further work is necessary to evaluate the expression of various NOX proteins and cytosolic subunits in GCA lesions. The combined production of ROS and NO in vascular tissue also leads to the production of peroxynitrite, which may contribute to the vascular injury through its ability to nitrate proteins [70]. Indeed, protein nitration in endothelial cells of medial microvessels has been demonstrated in GCA [169].
Giant Cell Tumors of Bone

Giant cell tumors of bone (GCTB; also called giant cell myeloma or osteoclastoma) is a rare and usually benign neoplasm that occurs in long bones [170]. GCTB are characterized by the presence of stromal fibroblast-like cells, macrophages and multinucleated giant cells that exhibit phenotypic features of osteoclasts [171]. Indeed, Roessner et al. [172] suggested that the multinucleated giant cells of GCTB were morphologically analogous to giant cells present in granulomas. It appears that the stromal fibroblast-like cells generate factors that recruit monocyte/ macrophages, and the supernatants of GCTB cell cultures possess chemotactic activity for osteoclast precursors [13]. Furthermore, Zheng et al. [13] proposed that transforming growth factor- $\beta 1$ plays a key role in recruitment osteoclasts and their precursors into the tumor.

ROS play an important role in GCTB, and proliferating GCTB is characterized by TRACP and NADH-tetrazolium reductase activity [173]. Quantitatively, TRACP activity was found to increase with increasing cell size, whereas the activity of NADH-tetrazolium reductase decreased proportionally [174]. Ciplea and coworkers [173, $174]$ proposed that this change was indicative of degeneration of the giant cells. Since the multinucleated giant cells associated with GCTB are osteoclast-like cells, which are known to generate significant levels of ROS, it is also likely that some form of NOX is expressed on these cells. Note, however, that the role of NADPH oxidase and ROS in the development of GCTB has not been determined.

\section{Summary}

Monocyte/macrophages are phagocytic leukocytes that play a multitude of functional roles in the body and represent key players in both innate and acquired immune systems. These cells also have the unique ability to fuse into multinucleated cells, which is a terminal differentiation pathway involved in a variety of physiological and pathological processes. Fusion of macrophages can result in the formation of osteoclasts or a variety of different multinucleated giant cells, each with unique properties and tissue distributions. Multinucleated giant cells are one of the characteristic features of granulomas and are able to attack extracellular material, such as larger pathogens and foreign material. Thus, their role in elimination of foreign substances, damaged tissue, and pathogens is essential to host survival. Furthermore, these cells are able to sequester irremovable material or persistent pathogens to prevent further spread of infection and iso- 
late foreign particles. The formation of multinucleated giant cells is a complex process induced by key cytokines and mediated by a number of fusogenic molecules and their receptors. Furthermore, it is clear that most, if not all, multinucleated giant cells generate ROS via activation of various NADPH oxidases, including those involving NOX1, NOX2 and NOX4. Indeed, the level of ROS produced by multinucleated giant cells is much greater than that of unfused cells. These ROS are not only involved in the inflammatory responses, but they also play an important regulatory role in macrophage multinucleation by inducing various fusion factors as well as modulating redox-sensitive transcription factors that are important in cell fusion. Nevertheless, there is still a lot of work needed to fully understand the function of NOX-based enzymes and their products in the development and function of multinucleated giant cells, especially in relation to their role in granulomas.

\section{Acknowledgements}

We would like to thank Dr. Yale Rosen (North Bellmore, N.Y., USA) for providing histological images of various giant cells. This work was supported in part by National Institutes of Health grant P20 RR-020185 and the Montana State University Agricultural Experimental Station.

\section{References}

1 Helming L, Gordon S: The molecular basis of macrophage fusion. Immunobiology 2007; 212:785-793

12 Vignery A: Macrophage fusion: molecular mechanisms. Methods Mol Biol 2008;475: 149-161.

3 Langhans T: Über Riesenzellen mit wandständigen Kernen in Tuberkeln und die fibröse Form des Tuberkels. Virchows Arch Pathol Anat 1868;382-404.

\4 Väänänen HK, Zhao H, Mulari M, Halleen JM: The cell biology of osteoclast function. J Cell Sci 2000;113:377-381.

5 Ruibal-Ares B, Riera NE, de Bracco MM: Macrophages, multinucleated giant cells, and apoptosis in HIV+ patients and normal blood donors. Clin Immunol Immunopathol 1997;82:102-116.

-6 Brodbeck, WG, Anderson JM: Giant cell formation and function. Curr Opin Hematol 2009; 16:53-57.

7 Aterman K, Remmele, W, Smith M: Karl Touton and his 'xanthelasmatic giant cell.' A selective review of multinucleated giant cells. Am J Dermatopathol 1988;10:257269.

8 Dayan D, Buchner A, Garlick J: Touton-like giant cells in periapical granulomas. J Endod 1989;15:210-211.

-9 Kodama H, Akiyama H, Nagao Y, Akagi O Nohara N: Persistence of foam cells in rabbit xanthoma after normalization of serum cholesterol level. Arch Dermatol Res 1988;280: 108-113.

-10 Consolaro A, Sant'Ana E, Lawall MA, Consolaro MF, Bacchi CE: Gingival juvenile xanthogranuloma in an adult patient: case report with immunohistochemical analysis and literature review. Oral Surg Oral Med Oral Pathol Oral Radiol Endod 2009;107: 246-252.
Fujikawa Y, Quinn JM, Sabokbar A, McGee JO, Athanasou NA: The human osteoclast precursor circulates in the monocyte fraction. Endocrinology 1996;137:4058-4060.

12 Vignery A: Osteoclasts and giant cells: macrophage-macrophage fusion mechanism. Int J Exp Pathol 2000;81:291-304.

13 Zheng MH, Fan Y, Wysocki SJ, Lau AT, Robertson T, Beilharz M, Wood DJ, Papadimitriou JM: Gene expression of transforming growth factor- $\beta 1$ and its type II receptor in giant cell tumors of bone. Possible involvement in osteoclast-like cell migration. Am J Pathol 1994;145:1095-1104.

14 Yasuda H, Shima N, Nakagawa N, Yamaguchi K, Kinosaki M, Mochizuki S, Tomoyasu A, Yano K, Goto M, Murakami A, et al: Osteoclast differentiation factor is a ligand for osteoprotegerin/osteoclastogenesis-inhibitory factor and is identical to TRANCE/ RANKL. Proc Natl Acad Sci USA 1998;95: 3597-3602.

15 McNally AK, Anderson JM: Interleukin-4 induces foreign body giant cells from human monocytes/macrophages. Differential lymphokine regulation of macrophage fusion leads to morphological variants of multinucleated giant cells. Am J Pathol 1995; 147: 1487-1499.

16 DeFife KM, Jenney CR, McNally AK, Colton E, Anderson JM: Interleukin-13 induces human monocyte/macrophage fusion and macrophage mannose receptor expression. J Immunol 1997; 158:3385-3390.

17 Helming L, Winter J, Gordon S: The scavenger receptor CD36 plays a role in cytokineinduced macrophage fusion. J Cell Sci 2009; 122:453-459.

18 Anderson JM: Multinucleated giant cells. Curr Opin Hematol 2000;7:40-47.
19 Reiss AB, Patel CA, Rahman MM, Chan ES, Hasneen K, Montesinos MC, Trachman JD, Cronstein BN: Interferon- $\gamma$ impedes reverse cholesterol transport and promotes foam cell transformation in THP-1 human monocytes/macrophages. Med Sci Monit 2004;10: BR420-BR425

20 Ikonomidis I, Stamatelopoulos K, Lekakis J, Vamvakou GD, Kremastinos DT: Inflammatory and non-invasive vascular markers: the multimarker approach for risk stratification in coronary artery disease. Atherosclerosis 2008;199:3-11.

21 Lietman SA, Yin L, Levine MA: SH3BP2 is an activator of NFAT activity and osteoclastogenesis. Biochem Biophys Res Commun 2008;371:644-648.

22 Xu J, Wu HF, Ang ES, Yip K, Woloszyn M, Zheng MH, Tan, RX: NF- $\kappa$ B modulators in osteolytic bone diseases. Cytokine Growth Factor Rev 2009;20:7-17.

23 Lee FY, Kim DW, Karmin JA, Hong D, Chang SS, Fujisawa M, Takayanagi H, Bigliani LU, Blaine TA, Lee HJ: $\mu$-Calpain regulates receptor activator of NF- $\kappa \mathrm{B}$ ligand (RANKL)supported osteoclastogenesis via NF- $\kappa \mathrm{B}$ activation in RAW 264.7 cells. J Biol Chem 2005;280:29929-29936.

24 Teitelbaum SL, Ross FP: Genetic regulation of osteoclast development and function. Nat Rev Genet 2003;4:638-649.

25 Hotokezaka H, Sakai E, Ohara N, Hotokezaka Y, Gonzales C, Matsuo K, Fujimura Y, Yoshida N, Nakayama K: Molecular analysis of RANKL-independent cell fusion of osteoclast-like cells induced by TNF- $\alpha$, lipopolysaccharide, or peptidoglycan. J Cell Biochem 2007;101:122-134.

26 Benoit M, Desnues B, Mege JL: Macrophage polarization in bacterial infections. J Immunol 2008;181:3733-3739. 
27 Varin A, Gordon S: Alternative activation of macrophages: immune function and cellular biology. Immunobiology 2009; in press.

-28 Anderson JM, Rodriguez A, Chang DT: Foreign body reaction to biomaterials. Semin Immunol 2008;20:86-100.

-29 Yagi M, Ninomiya K, Fujita N, Suzuki T, Iwasaki R, Morita K, Hosogane N, Matsuo K, Toyama Y, Suda T et al: Induction of DCSTAMP by alternative activation and downstream signaling mechanisms. J Bone Miner Res 2007;22:992-1001.

-30 Kim MS, Day CJ, Morrison NA: MCP-1 is induced by receptor activator of nuclear factor$\kappa \mathrm{B}$ ligand, promotes human osteoclast fusion, and rescues granulocyte macrophage colony-stimulating factor suppression of osteoclast formation. J Biol Chem 2005;280: 16163-16169.

-31 Low QE, Drugea IA, Duffner LA, Quinn DG, Cook DN, Rollins BJ, Kovacs EJ, DiPietro LA: Wound healing in MIP- $1 \alpha^{-/-}$and MCP$1^{-/-}$mice. Am J Pathol 2001;159:457-463.

>32 Brown EJ, Frazier, WA: Integrin-associated protein (CD47) and its ligands. Trends Cell Biol 2001;11:130-135.

33 Babic I, Schallhorn A, Lindberg FP, Jirik FR: SHPS-1 induces aggregation of $\mathrm{Ba} / \mathrm{F} 3$ pro- $\mathrm{B}$ cells via an interaction with CD47. J Immunol 2000;164:3652-3658.

-34 Han X, Sterling H, Chen Y, Saginario C, Brown EJ, Frazier WA, Lindberg FP, Vignery A: CD47, a ligand for the macrophage fusion receptor, participates in macrophage multinucleation. J Biol Chem 2000;275:3798437992.

-35 Harris ES, McIntyre TM, Prescott SM, Zimmerman GA: The leukocyte integrins. J Biol Chem 2000;275:23409-23412.

-36 McNally AK, Anderson JM: $\beta 1$ and $\beta 2$ integrins mediate adhesion during macrophage fusion and multinucleated foreign body giant cell formation. Am J Pathol 2002;160: 621-630.

-37 McNally AK, Macewan SR, Anderson JM: $\alpha$ Subunit partners to $\beta 1$ and $\beta 2$ integrins during IL-4-induced foreign body giant cell formation. J Biomed Mater Res A 2007;82:568574.

>38 Rao H, Lu G, Kajiya H, Garcia-Palacios V, Kurihara N, Anderson J, Patrene K, Sheppard D, Blair HC, Windle JJ, et al: $\alpha_{9} \beta_{1}$ : a novel osteoclast integrin that regulates osteoclast formation and function. J Bone Miner Res 2006;21:1657-1665.

-39 Collot-Teixeira S, Martin J, McDermott-Roe C, Poston R, McGregor JL: CD36 and macrophages in atherosclerosis. Cardiovasc Res 2007;75:468-477.

-40 Lee, WY, Kubes P: Leukocyte adhesion in the liver: distinct adhesion paradigm from other organs. J Hepatol 2008;48:504-512.

-41 Sterling H, Saginario C, Vignery A: CD44 occupancy prevents macrophage multinucleation. J Cell Biol 1998;143:837-847.
42 Cui, W, Ke JZ, Zhang Q, Ke HZ, Chalouni C, Vignery A: The intracellular domain of CD44 promotes the fusion of macrophages Blood 2006;107:796-805.

43 Minas K, Liversidge J: Is the CD200/CD200 receptor interaction more than just a myeloid cell inhibitory signal? Crit Rev Immunol 2006;26:213-230.

44 Cui, W, Cuartas E, Ke J, Zhang Q, Einarsson $\mathrm{HB}$, Sedgwick JD, Li J, Vignery A: CD200 and its receptor, CD200R, modulate bone mass via the differentiation of osteoclasts. Proc Natl Acad Sci USA 2007;104:1443614441.

45 Lee SH, Rho J, Jeong D, Sul JY, Kim T, Kim N, Kang JS, Miyamoto T, Suda T, Lee SK et al: v-ATPase V0 subunit d2-deficient mice exhibit impaired osteoclast fusion and increased bone formation. Nat Med 2006;12: 1403-1409.

$46 \mathrm{Wu} \mathrm{H}, \mathrm{Xu} \mathrm{G}$, Li YP: Atp6v0d2 is an essential component of the osteoclast-specific proton pump that mediates extracellular acidification in bone resorption. J Bone Miner Res 2009;24:871-885.

$\checkmark 47$ North RA: Molecular physiology of P2X receptors. Physiol Rev 2002;82:1013-1067.

48 Rassendren F, Buell GN, Virginio C, Collo G, North RA, Surprenant A: The permeabilizing ATP receptor, P2X7. Cloning and expression of a human cDNA. J Biol Chem 1997; 272:5482-5486.

49 Lemaire I, Falzoni S, Leduc N, Zhang B, Pellegatti P, Adinolfi E, Chiozzi P, Di VF: Involvement of the purinergic $\mathrm{P}_{2} \mathrm{X}_{7}$ receptor in the formation of multinucleated giant cells. J Immunol 2006;177:7257-7265.

50 Suda N, Morita I, Kuroda T, Murota S: Participation of oxidative stress in the process of osteoclast differentiation. Biochim Biophys Acta 1993;1157:318-323.

51 Steinbeck MJ, Kim JK, Trudeau MJ, Hauschka PV, Karnovsky MJ: Involvement of hydrogen peroxide in the differentiation of clonal HD-11EM cells into osteoclast-like cells. J Cell Physiol 1998;176:574-587.

52 Kim H, Kim IY, Lee SY, Jeong D: Bimodal actions of reactive oxygen species in the differentiation and bone-resorbing functions of osteoclasts. FEBS Lett 2006;580:5661-5665.

53 Kyung TW, Lee JE, Shin HH, Choi HS: Rutin inhibits osteoclast formation by decreasing reactive oxygen species and TNF- $\alpha$ by inhibiting activation of NF- $\mathrm{B}$. Exp Mol Med 2008;40:52-58.

54 Lee NK, Choi YG, Baik JY, Han SY, Jeong DW, Bae YS, Kim N, Lee SY: A crucial role for reactive oxygen species in RANKL-induced osteoclast differentiation. Blood 2005; 106:852-859.

55 Bai XC, Lu D, Liu AL, Zhang ZM, Li XM, Zou ZP, Zeng, WS, Cheng BL, Luo SQ: Reactive oxygen species stimulates receptor activator of NF- $\kappa \mathrm{B}$ ligand expression in osteoblast. J Biol Chem 2005;280:17497-17506.
56 Wang Y, Lebowitz D, Sun C, Thang H, Grynpas $\mathrm{MD}$, Glogauer M: Identifying the relative contributions of Rac1 and Rac2 to osteoclastogenesis. J Bone Miner Res 2008;23:260-270.

57 Liu J, Yang F, Yang XP, Jankowski M, Pagano PJ: $\mathrm{NAD}(\mathrm{P}) \mathrm{H}$ oxidase mediates angiotensin II-induced vascular macrophage infiltration and medial hypertrophy. Arterioscler Thromb Vasc Biol 2003;23:776-782.

58 Wang YH, Wang, WY, Liao JF, Chen CF, Hou YC, Liou KT, Chou YC, Tien JH, Shen YC: Prevention of macrophage adhesion molecule-1 (Mac-1)-dependent neutrophil firm adhesion by taxifolin through impairment of protein kinase-dependent NADPH oxidase activation and antagonism of $\mathrm{G}$ protein-mediated calcium influx. Biochem Pharmacol 2004;67:2251-2262.

59 Forman HJ, Torres M: Reactive oxygen species and cell signaling: respiratory burst in macrophage signaling. Am J Respir Crit Care Med 2002;166:S4-S8

60 Clark RA, Valente AJ: Nuclear factor $\kappa$ B activation by NADPH oxidases. Mech Ageing Dev 2004;125:799-810.

61 Simons K, Toomre D: Lipid rafts and signal transduction. Mol Cell Biol 2002;1:31-39.

$62 \mathrm{Ha} \mathrm{H}$, Kwak HB, Lee SK, Na DS, Rudd CE, Lee $\mathrm{ZH}$, Kim HH: Membrane rafts play a crucial role in receptor activator of nuclear factor $\kappa \mathrm{B}$ signaling and osteoclast function. J Biol Chem 2003;278:18573-18580.

63 Ishii M, Iwai K, Koike M, Ohshima S, KudoTanaka E, Ishii T, Mima T, Katada Y, Miyatake K, Uchiyama Y, et al: RANKL-induced expression of tetraspanin CD9 in lipid raft membrane microdomain is essential for cell fusion during osteoclastogenesis. J Bone Miner Res 2006;21:965-976.

64 Vilhardt F, Van Deurs B: The phagocyte NADPH oxidase depends on cholesterol-enriched membrane microdomains for assembly. EMBO J 2004;23:739-748.

65 Lu SP, Lin Feng MH, Huang HL, Huang YC, Tsou, WI, Lai MZ: Reactive oxygen species promote raft formation in $\mathrm{T}$ lymphocytes. Free Radic Biol Med 2007;42:936-944.

66 Quinn MT, Ammons MC, DeLeo FR: The expanding role of NADPH oxidases in health and disease: no longer just agents of death and destruction. Clin Sci 2006;111:1-20.

67 Steinbeck MJ, Appel, WH Jr, Verhoeven AJ, Karnovsky MJ: NADPH-oxidase expression and in situ production of superoxide by osteoclasts actively resorbing bone. J Cell Biol 1994;126:765-772.

68 Darden AG, Ries, WL, Wolf, WC, Rodriguiz RM, Key LL Jr: Osteoclastic superoxide production and bone resorption: stimulation and inhibition by modulators of NADPH oxidase. J Bone Miner Res 1996;11:671-675.

-69 Kreipe H, Radzun HJ, Rudolph P, Barth J, Hansmann ML, Heidorn K, Parwaresch MR: Multinucleated giant cells generated in vitro. Terminally differentiated macrophages with down-regulated c-fms expression. Am J Pathol 1988;130:232-243. 
70 Rittner HL, Kaiser M, Brack A, Szweda LI, Goronzy JJ, Weyand CM: Tissue-destructive macrophages in giant cell arteritis. Circ Res 1999;84:1050-1058.

71 Lay G, Poquet Y, Salek-Peyron P, Puissegur MP, Botanch C, Bon H, Levillain F, Duteyrat JL, Emile JF, Altare F: Langhans giant cells from $M$. tuberculosis-induced human granulomas cannot mediate mycobacterial uptake. J Pathol 2007;211:76-85.

72 Yang S, Ries WL, Key LL Jr: Nicotinamide adenine dinucleotide phosphate oxidase in the formation of superoxide in osteoclasts. Calcif Tissue Int 1998;63:346-350.

73 Yang S, Madyastha P, Bingel S, Ries W, Key L: A new superoxide-generating oxidase in murine osteoclasts. J Biol Chem 2001;276: 5452-5458.

74 Yang S, Zhang YZ, Ries W, Key L: Expression of Nox4 in osteoclasts. J Cell Biochem 2004; 92:238-248.

75 Liberman M, Bassi E, Martinatti MK, Lario FC, Wosniak J Jr, Pomerantzeff PM, Laurindo FR: Oxidant generation predominates around calcifying foci and enhances progression of aortic valve calcification. Arterioscler Thromb Vasc Biol 2008;28:463470.

76 Sumimoto H: Structure, regulation and evolution of Nox-family NADPH oxidases that produce reactive oxygen species. FEBS J 2008;275:3249-3277.

77 Kawahara T, Quinn MT, Lambeth JD: Molecular evolution of the reactive oxygen-generating NADPH oxidase (Nox/Duox) family of enzymes. BMC Evolut Biol 2007;7.

78 Cathcart MK, McNally AK, Morel DW, Chisolm GM III: Superoxide anion participation in human monocyte-mediated oxidation of low-density lipoprotein and conversion of low-density lipoprotein to a cytotoxin. J Immunol 1989;142:1963-1969.

79 Dewald B, Payne TG, Baggiolini M: Activation of NADPH oxidase of human neutrophils. Potentiation of chemotactic peptide by a diacylglycerol. Biochem Biophys Res Commun 1984;125:367-373.

80 Carlyon JA, Latif DA, Pypaert M, Lacy P, Fikrig E: Anaplasma phagocytophilum utilizes multiple host evasion mechanisms to thwart NADPH oxidase-mediated killing during neutrophil infection. Infect Immun 2004;72: 4772-4783.

81 Cathcart MK: Regulation of superoxide anion production by NADPH oxidase in monocytes/macrophages - contributions to atherosclerosis. Arterioscler Thromb Vasc Biol 2004;24:23-28.

-82 Gabay C: Interleukin-6 and chronic inflammation. Arthritis Res Ther 2006;8(suppl 2): S3.

-83 Gauss KA, Nelson-Overton LK, Siemsen DW, Gao Y, DeLeo FR, Quinn MT: Role of $\mathrm{NF}-\kappa \mathrm{B}$ in transcriptional regulation of the phagocyte NADPH oxidase by tumor necrosis factor- $\alpha$. J Leukoc Biol 2007;82:729-741.
84 Key LL Jr, Ries WL, Taylor RG, Hays BD, Pitzer BL: Oxygen derived free radicals in osteoclasts: the specificity and location of the nitroblue tetrazolium reaction. Bone 1990; 11:115-119.

85 Ries, WL, Key LL Jr, Rodriguiz RM: Nitroblue tetrazolium reduction and bone resorption by osteoclasts in vitro inhibited by a manganese-based superoxide dismutase mimic. J Bone Miner Res 1992;7:931-939.

86 Martyn KD, Frederick LM, von Löhneysen K, Dinauer MC, Knaus UG: Functional analysis of Nox4 reveals unique characteristics compared to other NADPH oxidases. Cell Signal 2006;18:69-82.

87 Garrett IR, Boyce BF, Oreffo RO, Bonewald L, Poser J, Mundy GR: Oxygen-derived free radicals stimulate osteoclastic bone resorption in rodent bone in vitro and in vivo. J Clin Invest 1990;85:632-639.

88 Mochizuki T, Furuta S, Mitsushita J, Shang, W, Ito M, Yokoo Y, Yamaura M, Ishizone S, Nakayama J, Konagai A, et al: Inhibition of NADPH oxidase 4 activates apoptosis via the AKT/apoptosis signal-regulating kinase 1 pathway in pancreatic cancer PANC-1 cells. Oncogene 2006;25:3699-3707.

$>89$ Segal BH, Romani L, Puccetti P: Chronic granulomatous disease. Cell Mol Life Sci 2009;66:553-558.

90 Dennis CG, Greco, WR, Brun Y, Youn R, Slocum HK, Bernacki RJ, Lewis R, Wiederhold N, Holland SM, Petraitiene R, et al: Effect of amphotericin $\mathrm{B}$ and micafungin combination on survival, histopathology, and fungal burden in experimental aspergillosis in the p47phox-l- mouse model of chronic granulomatous disease. Antimicrob Agents Chemother 2006;50:422-427.

-91 Arimura Y, Goto A, Yamashita K, Endo T, Ikeda H, Tanaka K, Tsutsumi H, Shinomura Y, Imai K: Intractable colitis associated with chronic granulomatous disease. J Med Microbiol 2006;55:1587-1590.

$\$ 92$ Malech HL, Hickstein DD: Genetics, biology and clinical management of myeloid cell primary immune deficiencies: chronic granulomatous disease and leukocyte adhesion deficiency. Curr Opin Hematol 2007;14:29-36.

-93 Kobayashi SD, Voyich JM, Braughton KR, Whitney AR, Nauseef, WM, Malech HL, DeLeo FR: Gene expression profiling provides insight into the pathophysiology of chronic granulomatous disease. J Immunol 2004; 172:636-643.

94 Baniulis D, Nakano Y, Nauseef, WM, Banfi B, Cheng G, Lambeth DJ, Burritt JB, Taylor RM, Jesaitis AJ: Evaluation of two anti-gp91phox antibodies as immunoprobes for Nox family proteins: $\mathrm{mAb} 54.1$ recognizes recombinant full-length Nox2, Nox3 and the C-terminal domains of Nox1-4 and crossreacts with GRP 58. Biochim Biophys Acta 2005;1752:186-196.
95 Segal BH, Sakamoto N, Patel M, Maemura K, Klein AS, Holland SM, Bulkley GB: Xanthine oxidase contributes to host defense against Burkholderia cepacia in the p47 phox-l- mouse model of chronic granulomatous disease. Infect Immun 2000;68: 2374-2378.

96 Mizuno K, Okamoto H, Horio T: Inhibitory influences of xanthine oxidase inhibitor and angiotensin I-converting enzyme inhibitor on multinucleated giant cell formation from monocytes by downregulation of adhesion molecules and purinergic receptors. Br J Dermatol 2004;150:205-210.

$\checkmark 97$ Hewinson J, Moore SF, Glover C, Watts AG, MacKenzie AB: A key role for redox signaling in rapid $\mathrm{P} 2 \mathrm{X} 7$ receptor-induced IL-1 $\beta$ processing in human monocytes. J Immunol 2008;180:8410-8420.

$\checkmark 98$ Alblas J, Honing H, de Lavalette CR, Brown MH, Dijkstra CD, van den Berg TK: Signal regulatory protein alpha ligation induces macrophage nitric oxide production through JAK/STAT- and phosphatidylinositol 3-kinase/Rac1/NADPH oxidase/ $\mathrm{H}_{2} \mathrm{O}_{2}$-dependent pathways. Mol Cell Biol 2005;25:7181-7192.

$\checkmark 99$ Kim Y, Lee YS, Choe J, Lee H, Kim YM, Jeoung D: CD44-epidermal growth factor receptor interaction mediates hyaluronic acid-promoted cell motility by activating protein kinase $\mathrm{C}$ signaling involving Akt, Rac1, Phox, reactive oxygen species, focal adhesion kinase, and MMP-2. J Biol Chem 2008;283:22513-22528.

100 Halleen JM, Räisänen SR, Alatalo SL, Väänänen HK: Potential function for the ROSgenerating activity of TRACP. J Bone Miner Res 2003;18:1908-1911.

101 Halleen JM, Räisänen SR, Salo JJ, Reddy SV, Roodman GD, Hentunen TA, Lehenkari PP, Kaija H, Vihko P, Väänänen HK: Intracellular fragmentation of bone resorption products by reactive oxygen species generated by osteoclastic tartrate-resistant acid phosphatase. J Biol Chem 1999;274:2290722910.

102 Räisänen SR, Alatalo SL, Ylipahkala H, Halleen JM, Cassady AI, Hume DA, Väänänen HK: Macrophages overexpressing tartrate-resistant acid phosphatase show altered profile of free radical production and enhanced capacity of bacterial killing. Biochem Biophys Res Commun 2005;331:120126.

103 Seitzer U, Scheel-Toellner D, Toellner KM, Reiling N, Haas H, Galle J, Flad HD, Gerdes $\mathrm{J}$ : Properties of multinucleated giant cells in a new in vitro model for human granuloma formation. J Pathol 1997;182:99-105.

104 Vignery A: Macrophage fusion: are somatic and cancer cells possible partners? Trends Cell Biol 2005;15:188-193.

105 Adams DO: The granulomatous inflammatory response. A review. Am J Pathol 1976;84:164-192. 
106 Epstein WL, Fukuyama K: Mechanisms of granulomatous inflammation. Immunol Ser 1989;46:687-721.

- 107 Akritidis N, Tzivras M, Delladetsima I, Stefanaki S, Moutsopoulos HM, Pappas G: The liver in brucellosis. Clin Gastroenterol Hepatol 2007;5:1109-1112.

-108 Jain V, Dabir S, Shome D, Dadu T, Natarajan S: Aspergillus iris granuloma: a case report with review of literature. Surv Ophthalmol 2009;54:286-291.

- 109 Shibuya K, Hirata A, Omuta J, Sugamata M, Katori S, Saito N, Murata N, Morita A, Takahashi K, Hasegawa C, et al: Granuloma and cryptococcosis. J Infect Chemother 2005;11:115-122.

-110 Lockwood DN, Lucas SB, Desikan KV, Ebenezer G, Suneetha S, Nicholls P: The histological diagnosis of leprosy type 1 reactions: identification of key variables and an analysis of the process of histological diagnosis. J Clin Pathol 2008;61:595-600.

-111 Hogan LH, Markofski, W, Bock A, Barger B, Morrissey JD, Sandor M: Mycobacterium bovis BCG-induced granuloma formation depends on $\gamma$ interferon and CD40 ligand but does not require CD28. Infect Immun 2001;69:2596-2603.

-112 Byrd TF: Multinucleated giant cell formation induced by IFN- $\gamma / \mathrm{IL}-3$ is associated with restriction of virulent Mycobacterium tuberculosis cell to cell invasion in human monocyte monolayers. Cell Immunol 1998; 188:89-96.

-113 Saunders BM, Cooper AM: Restraining mycobacteria: role of granulomas in mycobacterial infections. Immunol Cell Biol 2000;78:334-341.

114 Rodriguez A, Macewan SR, Meyerson H, Kirk JT, Anderson JM: The foreign body reaction in T-cell-deficient mice. J Biomed Mater Res A 2008.

-115 Mizuno K, Okamoto H, Horio T: Muramyl dipeptide and mononuclear cell supernatant induce Langhans-type cells from human monocytes. J Leukoc Biol 2001;70: 386-394.

-116 Okamoto H, Mizuno K, Horio T: Monocyte-derived multinucleated giant cells and sarcoidosis. J Dermatol Sci 2003;31:119128.

- 117 Pereira-Suárez AL, Estrada-Chavez C, Arriaga-Diaz C, Espinosa-Cueto P, Mancilla R: Coexpression of NRAMP1, iNOS, and nitrotyrosine in bovine tuberculosis. Vet Pathol 2006;43:709-717.

-118 Damle A, Mahadevan PR: In vivo effect of delipidified cell component of Mycobacterium leprae in relation to infection with leprosy bacteria in mice. Indian J Lepr 1993;65: 271-282.

- 119 Pham NK, Mouriz J, Kima PE: Leishmania pifanoi amastigotes avoid macrophage production of superoxide by inducing heme degradation. Infect Immun 2005;73:83228333.
120 Bylund J, Goldblatt D, Speert DP: Chronic granulomatous disease: from genetic defect to clinical presentation. Adv Exp Med Biol 2005;568:67-87.

121 Kottilil S, Malech HL, Gill VJ, Holland SM: Infections with Haemophilus species in chronic granulomatous disease: insights into the interaction of bacterial catalase and $\mathrm{H}_{2} \mathrm{O}_{2}$ production. Clin Immunol 2003; $106: 226-230$

122 Woodman RC, Erickson RW, Rae J, Jaffe HS, Curnutte JT: Prolonged recombinant interferon-gamma therapy in chronic granulomatous disease - evidence against enhanced neutrophil oxidase activity. Blood 1992;79:1558-1562.

123 Black MM, Epstein, WL: Formation of mul tinucleate giant cells in organized epitheloid cell granulomas. Am J Pathol 1974;74: 263-274.

124 Anderson JM, Jones JA: Phenotypic dichotomies in the foreign body reaction. Biomaterials 2007;28:5114-5120.

125 Moreno JL, Mikhailenko I, Tondravi MM Keegan AD: IL-4 promotes the formation of multinucleated giant cells from macrophage precursors by a STAT6-dependent, homotypic mechanism: contribution of E-cadherin. J Leukoc Biol 2007;82:15421553.

126 McNally AK, Jones JA, Macewan SR, Colton E, Anderson JM: Vitronectin is a critical protein adhesion substrate for IL-4-induced foreign body giant cell formation. Biomed Mater Res A 2008;86:535-543.

127 Wang ML, Hauschka PV, Tuan RS, Steinbeck MJ: Exposure to particles stimulates superoxide production by human THP-1 macrophages and avian HD-11EM osteoclasts activated by tumor necrosis factor- $\alpha$ and PMA. J Arthroplasty 2002;17:335346.

128 Gristina AG: Implant failure and the immuno-incompetent fibro-inflammatory zone. Clin Orthop Relat Res 1994;106-118.

$>129$ Lee KH, Chu CC: The role of superoxide ions in the degradation of synthetic absorbable sutures. J Biomed Mater Res 2000;49: 25-35.

130 Schubert MA, Wiggins MJ, Anderson JM, Hiltner A: Comparison of two antioxidants for poly(etherurethane urea) in an accelerated in vitro biodegradation system. J Biomed Mater Res 1997;34:493-505.

131 Udipi K, Ornberg RL, Thurmond KB, Settle SL, Forster D, Riley D: Modification of inflammatory response to implanted biomedical materials in vivo by surface bound superoxide dismutase mimics. J Biomed Mater Res 2000;51:549-560.

-132 Suzuki R, Muyco J, McKittrick J, Frangos JA: Reactive oxygen species inhibited by titanium oxide coatings. J Biomed Mater Res A 2003;66:396-402.
133 Ward B, Anderson J, McVenes R, Stokes K: In vivo biostability of polyether polyurethanes with fluoropolymer surface modifying endgroups: resistance to biologic oxidation and stress cracking. J Biomed Mater Res A 2006;79:827-835

134 Torralba KD, Quismorio FP Jr: Sarcoidosis and the rheumatologist. Curr Opin Rheumatol 2009;21:62-70.

135 Spector, WG: Immunologic components of granuloma formation. Epithelioid cells, giant cells, and sarcoidosis. Ann N Y Acad Sci 1976;278:3-6.

136 Singh M, Kothur K: Pulmonary sarcoidosis masquerading as tuberculosis. Indian Pediatr 2007;44:615-617.

137 Papaetis GS, Pefanis A, Solomon S, Tsangarakis I, Orphanidou D, Achimastos A: Asymptomatic stage I sarcoidosis complicated by pulmonary tuberculosis: a case report. J Med Case Reports 2008;2:226.

138 Schaberg T, Rau M, Stephan H, Lode H: Increased number of alveolar macrophages expressing surface molecules of the CD11/ CD18 family in sarcoidosis and idiopathic pulmonary fibrosis is related to the production of superoxide anions by these cells. Am Rev Respir Dis 1993;147:1507-1513.

139 Wilkinson LS, Pitsillides AA, Edwards JC: Giant cells in arthritic synovium. Ann Rheum Dis 1993;52:182-184.

140 Weinberg JB, Wortham TS, Misukonis MA, Patton KL, Chitneni SR: Synovial mononuclear phagocytes in rheumatoid arthritis and osteoarthritis: quantitative and functional aspects. Immunol Invest 1993;22:365-374.

141 Takano H, Tomita T, Toyosaki-Maeda T, Maeda-Tanimura M, Tsuboi $\mathrm{H}$, Takeuchi E, Kaneko M, Shi K, Takahi K, Myoui A, et al: Comparison of the activities of multinucleated bone-resorbing giant cells derived from CD14-positive cells in the synovial fluids of rheumatoid arthritis and osteoarthritis patients. Rheumatology (Oxford) 2004;43:435-441.

142 Ainola M, Mandelin J, Liljestrom M, Konttinen YT, Salo J: Imbalanced expression of RANKL and osteoprotegerin mRNA in pannus tissue of rheumatoid arthritis. Clin Exp Rheumatol 2008;26:240-246.

143 Miesel R, Hartung R, Kroeger H: Priming of NADPH oxidase by tumor necrosis factor alpha in patients with inflammatory and autoimmune rheumatic diseases. Inflammation 1996;20:427-438.

144 't Hart BA, Simons JM, Knaan-Shanzer S, Bakker NPM, LaBadie RP: Antiarthritic activity of the newly developed neutrophil oxidative burst antagonist apocynin. Free Radic Biol Med 1990;9:127-131.

- 145 Cronstein BN, Eberle MA, Gruber HE, Levin RI: Methotrexate inhibits neutrophil function by stimulating adenosine release from connective tissue cells. Proc Natl Acad Sci USA 1991;88:2441-2445. 
-146 Miesel R, Kurpisz M, Kröger H: Suppression of inflammatory arthritis by simultaneous inhibition of nitric oxide synthase and NADPH oxidase. Free Radic Biol Med 1996;20:75-81.

- 147 Van de Loo, FAJ, Bennink MB, Arntz OJ, Smeets RL, Lubberts E, Joosten LAB, van Lent PLEM, Coenen-de Roo CJJ, Cuzzocrea $\mathrm{S}$, Segal BH, et al: Deficiency of NADPH oxidase components p47phox and gp91 phox caused granulomatous synovitis and increased connective tissue destruction in experimental arthritis models. Am J Pathol 2003; 163:1525-1537.

-148 Olofsson P, Holmberg J, Tordsson J, Lu S, Akerstrom B, Holmdahl R: Positional identification of $\mathrm{Ncf1}$ as a gene that regulates arthritis severity in rats. Nat Genet 2003;33: 25-32.

-149 Hultqvist M, Olofsson P, Holmberg J, Backstrom BT, Tordsson J, Holmdahl R: Enhanced autoimmunity, arthritis, and encephalomyelitis in mice with a reduced oxidative burst due to a mutation in the Ncf1 gene. Proc Natl Acad Sci USA 2004; 101:12646-12651.

150 Bryant PA, Robins-Browne R, Carapetis JR, Curtis N: Some of the people, some of the time: susceptibility to acute rheumatic fever. Circulation 2009;119:742-753.

-151 Ferrans VJ, Rodriguez ER, McAllister HA Jr: Granulomatous inflammation of the heart. Heart Vessels Suppl 1985;1:262-270.

-152 Fraser, WJ, Haffejee Z, Cooper K: Rheumatic Aschoff nodules revisited: an immunohistological reappraisal of the cellular component. Histopathology 1995;27:457461.

153 Fraser, WJ, Haffejee Z, Jankelow D, Wadee A, Cooper K: Rheumatic Aschoff nodules revisited. II: cytokine expression corroborates recently proposed sequential stages. Histopathology 1997;31:460-464.

154 Kawasaki A, Purvin V: Giant cell arteritis: an updated review. Acta Ophthalmol 2009; 87:13-32.

155 Weyand CM, Goronzy JJ: Giant-cell arteritis and polymyalgia rheumatica. Ann Intern Med 2003;139:505-515.
156 Brack A, Geisler A, Martinez-Taboada VM, Younge BR, Goronzy JJ, Weyand CM: Giant cell vasculitis is a $\mathrm{T}$ cell-dependent disease. Mol Med 1997;3:530-543.

-157 Martinez-Taboada VM, Alvarez L, RuizSoto M, Marin-Vidalled MJ, Lopez-Hoyos M: Giant cell arteritis and polymyalgia rheumatica: role of cytokines in the pathogenesis and implications for treatment. Cytokine 2008;44:207-220

158 Nordborg E, Bengtsson BA, Petursdottir V, Nordborg C: Morphological aspects of giant cells in giant cell arteritis: an electronmicroscopic and immunocytochemical study. Clin Exp Rheumatol 1997;15:129134.

159 Nordborg E, Nordborg C: Giant cell arteritis: epidemiological clues to its pathogenesis and an update on its treatment. Rheumatology 2003;42:413-421.

160 Ma-Krupa, W, Jeon MS, Spoerl S, Tedder TF, Goronzy JJ, Weyand CM: Activation of arterial wall dendritic cells and breakdown of self-tolerance in giant cell arteritis. J Exp Med 2004;199:173-183.

161 Coury F, Annels N, Rivollier A, Olsson S, Santoro A, Speziani C, Azocar O, Flacher M, Djebali S, Tebib J, et al: Langerhans cell histiocytosis reveals a new IL-17A-dependent pathway of dendritic cell fusion. Nat Med 2008;14:81-87.

162 Ma-Krupa, W, Dewan M, Jeon MS, Kurtin PJ, Younge BR, Goronzy JJ, Weyand CM: Trapping of misdirected dendritic cells in the granulomatous lesions of giant cell arteritis. Am J Pathol 2002;161:1815-1823.

163 Weyand CM, Goronzy JJ: Pathogenic mechanisms in giant cell arteritis. Cleve Clin J Med 2002;69(suppl 2):SII28-SII32.

164 Shionoya S, Tsunekawa S, Kamiya K: Elastolysis and giant cell reaction against disintegrated elastic fibres. Nature 1965;207: 311-312.

165 Gillot JM, Masy E, Davril M, Hachulla E, Hatron PY, Devulder B, Dessaint JP: Elastase derived elastin peptides: putative autoimmune targets in giant cell arteritis. J Rheumatol 1997;24:677-682.
166 McCormick MM, Rahimi F, Bobryshev YV, Gaus K, Zreiqat H, Cai H, Lord RSA, Geczy CL: S100A8 and S100A9 in human arterial wall - Implications for atherogenesis. J Biol Chem 2005;280:41521-41529.

167 Hessian PA, Edgeworth J, Hogg N: MRP-8 and MRP-14, two abundant $\mathrm{Ca}^{2+}$-binding proteins of neutrophils and monocytes. J Leukoc Biol 1993;53:197-204.

168 Kerkhoff C, Nacken, W, Benedyk M, Dagher MC, Sopalla C, Doussiere J: The arachidonic acid-binding protein S100A8/A9 promotes NADPH oxidase activation by interaction with p67phox and Rac-2. FASEB J 2005;19:467-469.

169 Borkowski A, Younge BR, Szweda L, Mock B, Bjornsson J, Moeller K, Goronzy JJ, Weyand CM: Reactive nitrogen intermediates in giant cell arteritis: selective nitration of neocapillaries. Am J Pathol 2002;161:115123.

170 Goldring SR, Roelke MS, Petrison KK, Bhan AK: Human giant cell tumors of bone identification and characterization of cell types. J Clin Invest 1987;79:483-491.

171 Zheng $\mathrm{MH}$, Robbins $\mathrm{P}, \mathrm{Xu}$ J, Huang L, Wood DJ, Papadimitriou JM: The histogenesis of giant cell tumour of bone: a model of interaction between neoplastic cells and osteoclasts. Histol Histopathol 2001;16:297307.

172 Roessner A, von Bassewitz DB, Schlake, W, Thorwesten G, Grundmann E: Biologic characterization of human bone tumors. III. Giant cell tumor of bone. A combined electron microscopical, histochemical, and autoradiographical study. Pathol Res Pract 1984;178:431-440.

173 Ciplea AG, Metze K, Grundmann E, Roessner A, Hettwer H: Microphotometric quantitation of enzyme activities in giant cell tumor of bone. A case study. Pathol Res Pract 1985;179:412-418.

174 Metze K, Ciplea AG, Hettwer H, Barckhaus RH: Size dependent enzyme activities of multinucleated (osteoclastic) giant cells in bone tumors. Pathol Res Pract 1987;182: 214-221. 